\title{
1 Identifying subsoil sediment sources with carbon and nitrogen stable isotope 2 ratios
}

3

4

5

6

\author{
J. Patrick Laceby ${ }^{\text {ab } * \text {, Jon Olley }}{ }^{\mathrm{b}}$, Timothy J. Pietsch ${ }^{\mathrm{b}}$, Fran Sheldon ${ }^{\mathrm{b}}$, Stuart E. Bunn ${ }^{\mathrm{b}}$ \\ ${ }^{a}$ Laboratoire des Sciences du Climat et de l'Environnement (LSCE/IPSL), Unité Mixte de Recherche 8212 \\ (CEA/CNRS/UVSQ), Gif-sur-Yvette Cedex, 91198, France \\ ${ }^{\mathrm{b}}$ Australian Rivers Institute, Griffith University, Nathan, QLD 4111, Australia \\ ${ }^{*}$ Corresponding author. \\ E-mail address: placeby@1sce.ipsl.fr \\ Phone No: +33 0782353548 \\ Fax No: +330169823568
}

Key Words: Sediment Tracing; Provenance; Australia; Subtropics

Short title: Tracing sediment sources with carbon and nitrogen stable isotope ratios

\begin{abstract}
.
Increased sediment loads from accelerated catchment erosion significantly degrade waterways worldwide. In the South East Queensland region of Australia, sediment loads are degrading Moreton Bay, a Ramsar listed wetland of international significance. In this region, like most parts of coastal Australia, sediment is predominantly derived from gully and channel bank erosion processes. A novel approach is presented that uses carbon and nitrogen stable isotope ratios and elemental composition to discriminate between these often indistinguishable subsoil sediment sources. The conservativeness of these sediment properties is first tested by examining the effect of particle size separation (testing for consistency during transport) and the effect of sampling at different times (testing for temporal source consistency). The discrimination potential of these sediment properties is then assessed with the conservative properties, based on the particle size and temporal analyses, modelled to determine sediment provenance in three catchments. Nitrogen sediment properties were found to have significant particle size enrichment and high temporal variance indicative of non-conservative behavior. Conversely, carbon stable isotopes had very limited particle size and temporal variability highlighting their suitability for sediment tracing. Channel erosion was modelled to be a significant source of sediment $(\mu 51 \%, \sigma 9 \%)$ contrasting desktop modelling research that estimated gully erosion is the predominant sediment source. To limit the supply of sediment to Moreton Bay, channel bank and gully erosion must both be targeted by sediment management programs. By distinguishing between subsoil sediment sources this approach has the potential to enhance the management of sediment loads degrading waterways worldwide.
\end{abstract}




\section{Introduction}

Suspended sediment can be detrimental to waterways, altering physical and chemical water quality attributes, impacting aquatic ecosystems, and increasing costs of water treatment and transportation infrastructure (Clark, 1985; Bilotta and Brazier, 2008; Collins et al., 2011). In Australia's South East Queensland (SEQ) region, anthropogenically increased sediment loads are degrading Moreton Bay, a Ramsar listed wetland of international significance (Bunn et al., 2007). Understanding the nature, location and relative contribution of sediment sources is therefore fundamental to the effective management of waterways in general, and Moreton Bay in particular (Wallbrink, 2004; Walling, 2005).

Although channel and gully erosion sources dominate the supply of suspended sediment in Australia (Wallbrink et al., 1998; Caitcheon et al., 2012; Olley et al., 2013b), cultivated land surfaces have also been identified as a significant source in SEQ (Caitcheon et al., 2001). Material eroded from cultivated land surfaces, gullies and channel banks typically has low fallout radionuclide concentrations $\left({ }^{137} \mathrm{Cs}\right.$ and $\left.{ }^{210} \mathrm{~Pb}_{\mathrm{ex}}\right)$ making it difficult to quantify their relative contribution to in-stream sediment. Here we present an approach that discriminates between subsoil sediment sources based on the analysis of carbon and nitrogen stable isotope ratios $\left(\delta^{13} \mathrm{C}\right.$ and $\left.\delta^{15} \mathrm{~N}\right)$ and elemental composition (total organic carbon (TOC) and total nitrogen (TN)).

$\delta^{13} \mathrm{C}$ may discriminate between sediment derived from landscapes covered with vegetation following the $\mathrm{C}_{3}$ or Calvin-Benson photosynthetic pathway (such as the majority of tree or temperate grass species) from landscapes covered with vegetation following the $\mathrm{C}_{4}$ or Hatch-Slack cycle photosynthetic pathway (several grass and cropping species predominantly found in warmer climates) (Schimel, 1993; Fry, 2006). Soil with $\mathrm{C}_{3}$ inputs have $\delta^{13} \mathrm{C}$ values that range between $-24 \%$ and $-29 \%$ compared to soil with $\mathrm{C}_{4}$ inputs that range between -12\%o and -13\% (Schimel, 1993). In SEQ, 79\% of grass species follow the $\mathrm{C}_{4}$ photosynthetic pathway (Hattersley, 1983). Approximately two-thirds of the native vegetation has been cleared since European settlement in 1823 (Olley et al., 2013b). The clearing of native vegetation along with variable rainfall regime initiated gully erosion in the region (Saxton et al., 2012). The resultant gully erosion typically occurs on grassy $\left(\mathrm{C}_{4}\right)$ landscapes without woody vegetation, whereas channel banks have maintained some degree of woody $\left(\mathrm{C}_{3}\right)$ vegetative cover. Accordingly $\delta^{13} \mathrm{C}$ may discriminate between sediment derived from these distinct subsoil sources.

There are multiple factors underlying the potential of $\delta^{15} \mathrm{~N}$ to discriminate between subsoil sources. First, animal manure and manure derived fertilizers have high $\delta^{15} \mathrm{~N}$ (Finlay and Kendall, 2007). Second, soil $\delta^{15} \mathrm{~N}$ often increases with depth in the soil profile (Natelhoffer and Fry, 1988; Amundson et al., 2003). Third, topographic position may impact soil $\delta^{15} \mathrm{~N}$ as landscapes, such as channel banks 
1 that are more likely to be subject to anaerobic conditions, may have increased denitrification favoring

2 the accumulation of ${ }^{15} \mathrm{~N}$ (Karamanos and Rennie, 1980; Mukundan et al., 2010). Accordingly, $\delta^{15} \mathrm{~N}$

3 may discriminate between cultivated sources with waste-derived fertilizer inputs and subsoil channel

4 and gully sources; it may also discriminate between surface and subsoil sources; and between gully

5 and channel sources.

6 TOC and TN have potential to discriminate between surface and subsoil sources as their

7 concentration decreases with depth in the soil profile (Blake et al., 2006; Owens et al., 2006). Further

8 there is less TOC in cultivated soils than surface soils because of tillage and harvesting (Walling et

9 al., 1993; Walling and Woodward, 1995; Juracek and Ziegler, 2009).

10 For carbon and nitrogen sediment properties to be effective tracers of sediment, they must 11 differentiate between sediment sources whilst behaving conservatively (Walling et al., 1993).

12 Conservative behavior is characterized by constancy in sediment properties where the source of

13 sediment remains constant, or at the very least any variation in sediment properties should occur in a

14 predictable way. In addition, properties of the eroded sediment must remain constant through

15 sediment generation, transportation, and deposition processes, or again vary in a predictable way

16 (Olley et al., 2001; Motha et al., 2002; Koiter et al., 2013).

To investigate the conservativeness of the sediment properties of interest $\left(\delta^{13} \mathrm{C}, \delta^{15} \mathrm{~N}\right.$, TOC and $\mathrm{TN}$ ), we first examined whether or not these attributes remained constant across different particle size fractions taken from single samples. This was done because particle size fractionation is one of the most important factors in the selective mobilization of sediment (Olley et al., 2001; Motha et al., 2002). Hence it is necessary to understand particle size fractionation effects that may limit the applicability of these properties in sediment tracing research. The temporal variation of these sediment properties is also examined by sampling potential source soils on two occasions. Following these investigations we modelled the conservative sediment properties providing discrimination between sources to identify the dominant sediment sources in the three catchments in South East Queensland (SEQ), Australia.

\section{Study Area}

Located on the eastern coast of Australia, the SEQ region has a population of $\sim 2.73$ million with the majority located in Brisbane, the region's major urban centre. SEQ is subtropical with mean maximum monthly temperatures ranging between 21 and $29^{\circ} \mathrm{C}$. Total annual rainfall ranges between 900 and $1800 \mathrm{~mm}$, with the majority falling during summer (October to February). Dominant land uses include bushland (37\%) and grazing (35\%) along with managed forest and plantations (9\%), developed areas (7\%), and agriculture (6\%) (Olley et al., 2013b). 
Samples were collected from three SEQ catchments: Knapp Creek, the Upper Bremer River and

2 Blackfellow Creek (Figure 1). These specific catchments were selected as part of a broader research

3 program focused on the development of appropriate sediment management strategies for the region

4 (Olley et al., 2009a). Knapp Creek $\left(75 \mathrm{~km}^{2}\right)$ is dominated by grazing with only $22 \%$ of the original

5 woody vegetation remaining (Olley et al., 2009b). The upper catchment contains largely un-incised

6 drainage lines and while there is localized channel erosion in areas of the upper catchment, sediment

7 production from this area is apparently limited. The middle reaches are largely devoid of woody

8 vegetation with considerable hillslope erosion and extensive gullies well-connected to the main

9 channel. Hillslope and gully erosion is also apparent in the lower catchment though well separated

10 from the main channel by large valley floors. Sediment budgets, derived with a modified version of

11 the SedNet modelling approach, estimated that gully erosion is the main source of sediment in Knapp

12 Creek (>90\%) (Olley et al., 2009b).

The Upper Bremer River catchment $\left(123 \mathrm{~km}^{2}\right)$ has been partly cleared with $46 \%$ woody vegetation remaining (Olley et al., 2010a). The steep upper catchments are primarily used for grazing and the higher slope areas are generally covered with dense woody vegetation. Although there are localized areas of erosion in the upper region, there is little evidence of significant sediment production. The downstream catchments have a mixture of land-uses including dairy, cultivation and grazing on the wide alluvial floodplain with extensive channel erosion evident in the lower catchment areas. Gully erosion was estimated with a modified version of the SedNet modelling approach as the main sediment source in the Upper Bremer River (>80\%)(Olley et al., 2010a).

The Blackfellow Creek catchment $\left(311 \mathrm{~km}^{2}\right)$ has been partly cleared with $38 \%$ remnant vegetation cover (Olley et al., 2010b). Land use in the headwaters upstream of the focal catchment is primarily low intensity grazing with vegetated uplands contributing limited sediment aside from isolated bank erosion during large events. The uplands in the lower catchments have been extensively cleared and the alluvial flats are intensively cultivated. A modified version of the SedNet modelling approach estimated that sediments are derived from a mixture of cultivated ( $40 \%)$, channel $(\sim 30 \%)$ and hillslope sources ( 30\%) (Olley et al., 2010b).

\section{Methods}

\section{Fluvial Fractionation Sampling}

30 To understand potential fluvial fractionation impacts on surface and subsurface soils, depth core samples were taken in Knapp Creek and Blackfellow Creek. In Knapp Creek, short vertical cores were taken from the top bank of 3 gully and 3 channel sites. Five cores were taken at each site, with soil sampled in $5 \mathrm{~cm}$ intervals to a depth of $30 \mathrm{~cm}$ with samples from each depth increment from the five replicate cores composited into one sample. Top $1-2 \mathrm{~cm}$ soil samples were also collected by 
1 compositing 20 surface trowel scrapes, taken within $2 \mathrm{~m}$ of the gully and channel banks over a $10 \mathrm{~m}$

2 reach, into one sample. In Blackfellow Creek, cores were similarly sampled from 3 cultivated and 3

3 grazing sites with $1-2 \mathrm{~cm}$ trowel scrape samples collected within $100 \mathrm{~m}^{2}$ quadrants. The $1-2,0-5,11-$

415 , and $26-30 \mathrm{~cm}$ core samples were fractionated into the $<2 \mu \mathrm{m},<10 \mu \mathrm{m},<63 \mu \mathrm{m}, \&<2 \mathrm{~mm}$ particle

5 size fractions using the methods described below. The $<10 \mu \mathrm{m}$ and $<63 \mu \mathrm{m}$ particle size fractions were

6 selected as these fractions are typically used to trace sediment in Australian (Olley and Caitcheon,

7 2000; Wallbrink, 2004; Wilkinson et al., 2013) and European (Walling et al., 1999; Carter et al.,

8 2003; Collins et al., 2012) research respectively. The $<2 \mu \mathrm{m}$ fraction represents material most likely

9 enriched in organic matter. The $<2 \mathrm{~mm}$ fraction represents the bulk soil fraction. Sampling occurred

10 between November and December 2009.

\section{Repetitive Source Sampling}

12 Temporal variability was examined by sampling multiple sources twice, between October and December 2009 and again between October and December 2010. At 13 sites, surface trowel scrape samples (top 1-2cm) were collected within $100 \mathrm{~m}^{2}$ quadrants. Additionally, six channel and three gully sites were sampled by scraping the sidewall from top bank to base three times over a $10 \mathrm{~m}$ reach, compositing scraped soils into one sample. Recently transported sediment at 3 gully sites was also sampled similarly to surface scrapes with our assumption being that there were no changes to the sources of sediment within this gully during the sampling period. The $<10 \mu \mathrm{m}$ fraction was analyzed for all samples.

\section{Source Discrimination Sampling}

To examine source discrimination potential, multiple samples were taken from the dominant sources in each catchment. In Knapp Creek surface scrapes (top 1-2cm) were taken from 12 grazing sites along with 11 channel and 7 gully sidewall scrapes (Figure 1). In the Upper Bremer River, surface scrapes were taken from 13 grazing sites along with 19 channel and 6 gully sidewall scrapes (Figure 1). In Blackfellow Creek, surface scrapes were taken from 14 cultivated, 21 grazing, and 6 natural grazing sites along with 15 channel sidewall scrapes (Figure 1). Cultivated and natural grazing sources were included in Blackfellow Creek because of the different land uses evident in the catchment; intensive cultivation is common on floodplains while extensive low-density grazing occurs in the forested headwaters. Further, in Blackfellow Creek, gully erosion is not considered a significant sediment source and accordingly it was not sampled. The $<10 \mu \mathrm{m}$ fraction was analyzed for all samples. Sampling occurred between April 2009 and December 2010.

\section{In-stream Sampling}

Multiple stream sampling sites were established in each catchment to develop a comprehensive understanding of sediment sources (Figure 1). Two approaches were used to sample in-stream 
1 sediment at each stream sampling site. The first sampled lag deposits; which are easily identifiable

2 distinct drapes of fine sediment remaining following flow events (Olley et al., 2003). Lag deposits

3 were sampled by compositing 20 trowel scrapes of the top $1-2 \mathrm{~cm}$ of evident lag material over a $100 \mathrm{~m}$

4 reach into one sample. The second approach involved the deployment of a time-integrated sampler

5 (Phillips et al., 2000) at each stream sampling site $\sim 0.5 \mathrm{~m}$ above the low water level. After each event,

6 samplers were drained into 20L buckets and returned to the lab for cleaning with new samplers

7 deployed. Three time-integrated samplers were destroyed during our research. Two small ponds

8 specifically designed to trap sediment during events were also sampled in Blackfellow Creek. These

9 ponds were excavated as they were nearing capacity. Following excavation, the removed sediment

10 was sampled by compositing 20 trowel grabs of the top $1 \mathrm{~cm}$ of excavated sediment into one sample.

11 A lag deposit was also sampled in one of the sediment traps. Sampling occurred between April 2009

12 and December 2010.

\section{Sample Preparation and Analyses}

The $<2 \mathrm{~mm}$ fraction was isolated by dry sieving following the disaggregation of large soil aggregates using a mortar and pestle. The $<63 \mu \mathrm{m}$ fraction was isolated by wet sieving. The $<2 \mu \mathrm{m}$ and $<10 \mu \mathrm{m}$ fractions were isolated using settling columns. The $<2 \mu \mathrm{m}$ and $<10 \mu \mathrm{m}$ supernatant was wet sieved $(63 \mu \mathrm{m})$ post settling to remove fragments of organic matter that may have remained in suspension following fractionation. For nitrogen analyses, samples were oven dried at $60^{\circ} \mathrm{C}$ for 48 hours, ground with a stainless steel ball-mill grinder and pelletized. For carbon, samples were treated repeatedly with $10 \% \mathrm{HCl}$ solution to remove carbonates until there was no longer evidence of effervescence (Kennedy et al., 2005). $\mathrm{HCl}$ treated samples were again oven dried at $60^{\circ} \mathrm{C}$ for 48 hours, pelletized, and weighed for analysis.

Samples were combusted using a Eurovector EA3000 (Milan, Italy) elemental analyser coupled to an Isoprime isotope-ratio mass spectrometer (GV Instruments, Manchester, UK) at the Australian Rivers Institute, Griffith University. The precision of TN and TOC were monitored using an Acetanilide elemental standard (TOC: $3.3 \%, \sigma 0.10 \%, \mathrm{TN}: 0.3 \%, \sigma 0.01 \%$ ). $\delta^{13} \mathrm{C}$ was monitored with an Australia's National University sucrose standard $\left(\delta^{13} \mathrm{C}:-12.2 \%, \sigma 0.16\right)$ and $\delta^{15} \mathrm{~N}$ with an International Atomic Energy Agency (IAEA-305a) surrogate standard $\left(\delta^{15} \mathrm{~N}: 0.3, \sigma 0.43\right)$.

\section{Data Analyses}

To investigate fluvial fractionation impacts on sediment TOC, TN, $\delta^{13} \mathrm{C}$ and $\delta^{15} \mathrm{~N}$, the $<2 \mu \mathrm{m}$, $<10 \mu \mathrm{m}$, and $<63 \mu \mathrm{m}$ fractions were normalised by dividing the analyte values of these fractions by their respective measures obtained from the bulk soil $(<2 \mathrm{~mm})$ fraction. This normalization allows the direct comparison of the impact of particle size variations on the different sediment properties. Kernel density estimates of the normalised fractions were then derived: 


$$
f(x)=\frac{1}{n h} \sum_{i=1}^{n} K\left(\frac{x-x_{i}}{h}\right)
$$

1 where $x_{1}, x_{2} \ldots x_{n}$ represent normalised particle size fraction samples having $n$ number of samples and

2 a density of $f$ with $h$ being the bandwidth parameter and $K$ the kernel with a uni-modal probability

3 density symmetric around zero derived from a Gaussian function (Sheather, 2004):

$$
K(x)=\frac{1}{\sqrt{2 \pi}} \exp \left(-\frac{x^{2}}{2}\right)
$$

4 Silverman's rule of thumb (Silverman, 1952) was used to calculate the bandwidth parameter $(h)$ :

$h=0.9 A n^{-1 / 5}$

5 where $A=\min$ (sample standard deviation, (sample interquartile range)/1.34))(Silverman, 1952;

6 Sheather, 2004). In addition, the bandwidth parameter $(h)$ was normalised for each sediment property:

$h(p)=\sum_{i=1}^{n}\left(\frac{h_{i}}{n}\right)$

7 where $p$ is the sediment property that a uniform $h$ parameter is being derived and $n$ is number of

8 normalised particle size fractions for which $h$ was calculated for each particle size fraction (i) in

9 Equation 3.

The following tests were used to establish statistical significance within our derived data sets. The

11 Shapiro-Wilk Test was used to determine whether normalised particle size fractions were normally distributed (Razali and Wah, 2011). The Levine test was used to determine if variances of two normalised fractions were homogenous and $t$-tests were used to determine significant differences between normalised fractions that with Gaussian distributions and homogenous variance (Dytham, 2003). For normalised fractions with significantly different variance or fractions that were not normally distributed, two-tailed Mann-Whitney U-tests tested for significant differences.

The temporal variation of sediment sources was examined by normalising the sediment properties of each sampling occasion by dividing them by the weighted mean of their equivalent sediment properties from both sampling occasions. Kernel density estimates were derived for each normalised sampling occasion by calculating an $h$ parameter for each sediment property for both sampling occasions (i) in Equation 4. Paired $t$-tests examined differences between sampling occasions that were normally distributed with homogeneous variance tested with the Shapiro Wilk test and the Levine test.

23 For sediment properties violating the assumptions of paired $t$-tests, Wilcoxon signed ranks test compared normalised sampling occasions. Where sources were sampled on multiple occasions, the weighted mean of the sediment properties from these sampling occasions was incorporated into source discrimination analysis and modelling. 
To examine source discrimination potential, kernel density estimates were derived with the inclusion of non-negative constraints for TOC and TN and the $h$ parameter for each sediment property was calculated with Equation 4 to normalise $h$ for all sources $(n)$. Owing to sample size, only MannWhitney U-tests were used to test for significant differences between sources as tests for normal distributions become increasingly less effective at small sample sizes (Razali and Wah, 2011). IBM's SPSS Statistics (v.21) was used for all statistical analyses.

\section{$7 \quad$ Sediment Source Modeling}

$\delta^{13} \mathrm{C}$ and $\delta^{15} \mathrm{~N}$ do not mix linearly as stable isotopes are dependent on their elemental concentrations (Phillips and Koch, 2002). Sediment tracing research examining compound specific carbon isotopes has used IsoSource software (Phillips and Gregg, 2003) and corrected for isotopic concentration dependency post-modelling (Gibbs, 2008; Blake et al., 2012; Hancock and Revill, 2013). For this current research, the concentration dependency was corrected within the distribution mixing model by summing elemental contributions (TOC\% and TN\%) and un-mixing the isotopic proportion $\left(\delta^{13} \mathrm{C}\right.$ and $\left.\delta^{15} \mathrm{~N}\right)$ of the elemental contribution in the mixture:

$$
M M D=\left|\left(\mathrm{C}_{\mathrm{e}}-\left(\sum_{s=1}^{m} \mathrm{P}_{\mathrm{s}} \mathrm{S}_{\mathrm{se}}\right)\right) / \mathrm{C}_{e}\right|+\left|\left(\mathrm{C}_{i}-\left(\left(\sum_{s=1}^{m} \mathrm{P}_{\mathrm{S}} \mathrm{S}_{\mathrm{se}} \mathrm{S}_{\mathrm{si}}\right) /\left(\sum_{s=1}^{m} \mathrm{P}_{\mathrm{S}} \mathrm{S}_{\mathrm{se}}\right)\right)\right) / \mathrm{C}_{i}\right|
$$

where $C_{e}$ is the elemental distribution of the in-stream sample grouping; $C_{i}$ is the isotopic distribution of the in-stream sample grouping; $m$ is the number of sources; $P_{s}$ is the source (s) distribution mixture contribution; $S_{s e}$ is the elemental distribution in source (s); $S_{s i}$ is the isotopic distribution in source (s) and MMD is the mixing model difference. Absolute values are summed in Equation 5 and the sediment properties selected for modelling are dependent upon their individual potential for discrimination in each catchment.

The proportional contribution from each source $\left(P_{s}\right)$ is modelled as a truncated normal distribution $(0 \leq \mathrm{x} \leq 1)$ with a mixture mean $\left(\mu_{m}\right)$ and standard deviation $\left(\sigma_{\mathrm{m}}\right)$ following the research of Caitcheon et al. (2012) and Olley et al. (2013b). Laceby and Olley (accepted) demonstrated that modelling normal distributions of source and in-stream sediment properties improves model accuracy compared to models sampling from Student's $t$-distributions. Accordingly normal distributions were modelled for all source and sediment distributions in this current research. Non-negative constraints were applied to the elemental distributions $\left(C_{e}\right.$ and $\left.S_{s e}\right)$ and the sum of all proportional contributions $\left(\mathrm{P}_{s}\right)$ was modelled to equal 1.

To model distributions, individual in-stream samples from Knapp Creek and the Upper Bremer River were grouped together by stream sites, whereas in Blackfellow Creek they were grouped by events. In Knapp Creek and the Upper Bremer River stream sampling site were longitudinally distributed throughout the catchment, whereas in Blackfellow Creek the sampling sites were 
1 concentrated in the lower reaches on the heavily cultivated alluvial flats. Accordingly Blackfellow

2 Creek has a much larger catchment area $\left(311 \mathrm{~km}^{2}\right)$ with the catchment area of stream sampling sites

3 only varying by $14 \%$ between the largest and the smallest catchment. In contrast, the variation

4 between largest and smallest catchment area of stream sites is $91 \%$ and $82 \%$ for Knapp Creek $\left(75 \mathrm{~km}^{2}\right)$

5 and the Upper Bremer River $\left(123 \mathrm{~km}^{2}\right)$ respectively.

6 Models were optimized with the Optquest algorithm in Oracle's Crystal Ball software that 7 incorporates distributions throughout a Monte Carlo style modelling framework (Laceby and Olley,

8 accepted). In Optquest, the $\mu_{\mathrm{m}}$ and $\sigma_{\mathrm{m}}$ for each source contribution distribution $\left(P_{s}\right)$ were repeatedly

9 varied when solving Equation 5 with 2500 Latin Hypercube samples drawn from each in-stream $\left(C_{e}\right.$ and $\left.C_{i}\right)$ and source $\left(S_{s i}\right.$ and $\left.S_{s e}\right)$ distribution. This determination of the optimal source contribution mixture $\left(P_{s}\right)$ for all 2500 in-stream and source distribution random deviates was repeated 2500 times. The median proportional contribution $\left(\mathrm{P}_{\mathrm{s}}\right)$ from all 2500 simulations was reported along with the median absolute deviation (MAD).

\section{Results and Discussion}

\section{Fluvial Fractionation}

Sediment TOC, TN, $\delta^{13} \mathrm{C}$ and $\delta^{15} \mathrm{~N}$ from multiple particle size fractions were normalised (i.e. by determining a ratio of each measurement to the equivalent measure obtained from the bulk sample) to facilitate comparison of the impact of fluvial fractionation on these different sediment properties. The normalised $<2 \mu \mathrm{m}$ fraction was most enriched for TN $(\mu 2.73)$ and TOC $(\mu 1.98)$ followed by the $<10 \mu \mathrm{m}$ (TN: $\mu$ 2.02, TOC: $\mu$ 1.79) and $<63 \mu \mathrm{m}$ fractions (TN: $\mu 1.65$, TOC: $\mu 1.52$ )(Figure 2). Less enrichment was evident for $\delta^{13} \mathrm{C}$ and $\delta^{15} \mathrm{~N}$. The $\delta^{15} \mathrm{~N}$ normalised $<2 \mu \mathrm{m}$ fraction was most enriched ( $\mu$ $1.28)$ followed by the $<10 \mu \mathrm{m}(\mu 1.21)$ and $<63 \mu \mathrm{m}$ fractions $(\mu 1.19)$. There was minor depletion for $\delta^{13} \mathrm{C}$ in the $<2 \mu \mathrm{m}$ normalised fraction $(\mu 0.97)$, with limited effects for the $<10 \mu \mathrm{m}(\mu 0.99)$ and $<63 \mu \mathrm{m}$ fractions $(\mu 1.00)$. Only $\delta^{13} \mathrm{C}$ had values across all particle size fractions that closely matched that measured in the bulk soil (Figure 2).

Distributions of measured $\delta^{13} \mathrm{C}$ were normal across all particle sizes fractions. Variance of the normalised $\delta^{13} \mathrm{C}$ fractions was not significantly different and accordingly t-tests indicated significant differences between the $<2 \mu \mathrm{m}$ and $<63 \mu \mathrm{m}$ fractions $(p<0.001)$ and the $<2 \mu \mathrm{m}$ and $<10 \mu \mathrm{m}$ fractions $(p$ $0.015)$. Although there were significant differences, they occurred within the range of $\delta^{13} \mathrm{C}$ analytical uncertainly $(\sigma 0.16)$. Mann Whitney (MW) U-tests reported significant differences between the TN $<2 \mu \mathrm{m}$ and $<63 \mu \mathrm{m}$ fraction (MW $p<0.001$ ), the TN $<10 \mu \mathrm{m}$ and $<63 \mu \mathrm{m}$ fraction (MW $p 0.044$ ), the $\delta^{15} \mathrm{~N}<2 \mu \mathrm{m}$ and $<10 \mu \mathrm{m}$ fraction (MW $p 0.013$ ), and the $\delta^{15} \mathrm{~N}<2 \mu \mathrm{m}$ and $<63 \mu \mathrm{m}$ fraction (MW $p$ $0.004)$. 
The TOC and TN enrichment was consistent with the literature as TOC and TN are generally reported to be enriched in the fine particle size fractions (Balesdent et al., 1987; Wynn et al., 2005).

3 For $\delta^{15} \mathrm{~N}$, the $<2 \mu \mathrm{m}$ fraction was most enriched, and significantly different from the $<10 \mu \mathrm{m}$ and

$4<63 \mu \mathrm{m}$ fractions. These differences were within the range of $\delta^{15} \mathrm{~N}$ analytical uncertainty $(\sigma 0.43)$

5 indicative of conservative behavior. The $\delta^{15} \mathrm{~N}$ enrichment in the fine particle size fractions was also consistent with the literature (Bellanger et al., 2004; Fox, 2005).

There was very limited $\delta^{13} \mathrm{C}$ variation across the particle size fractions. Stemmer et al. (1999) and Wynn et al. (2005) also reported no impact of particle size fractionation on $\delta^{13} \mathrm{C}$. Conversely, several authors reported different particle size effects with some finding $\delta^{13} \mathrm{C}$ enriched (Bellanger et al., 2004; Fox, 2005) or depleted (Balesdent et al., 1987). The particle size effects on $\delta^{13} \mathrm{C}$ are often related to the age of different particle size fractions and the age of the dominant vegetation regime (i.e. $\mathrm{C}_{3} / \mathrm{C}_{4}$ systems).

The objective of this analysis was to determine whether analyzing the $<2 \mu \mathrm{m}$ fraction would be significantly different from analyzing the $<10 \mu \mathrm{m}$ or $<63 \mu \mathrm{m}$ fraction. This is important as sediment generation processes result in suspended sediments being enriched with fine sediments. The results indicate that the particle size fraction analyzed will not impact $\delta^{13} \mathrm{C}$ and potentially not $\delta^{15} \mathrm{~N}$. Although TOC was enriched, none of the fractions was significantly different indicating the $<2 \mu \mathrm{m}$, $<10 \mu \mathrm{m}$, or $<63 \mu \mathrm{m}$ fraction may be used to trace sediment sources based on this analysis. Importantly, the particle size enrichment of TN must be addressed either through isolating the $<2 \mu \mathrm{m}$ or $<10 \mu \mathrm{m}$ particle size fraction, as these fractions were not found to be significantly different, or applying corrections during the modelling process.

As Smith and Blake (2014) demonstrated there are potential challenges with the incorporation of particle size corrections in sediment tracing research, we isolated the $<10 \mu \mathrm{m}$ fraction for all sediment properties for source discrimination analyses and modelling. The $<10 \mu \mathrm{m}$ fraction is the dominant particle size transported in the region (Douglas et al., 2003) and isolating this fraction mitigates the potential enrichment challenges with $\mathrm{TN}$ while minimizing potential differences between source and sediment particle size distributions for the other sediment properties (Wilkinson et al., 2013).

\section{Repetitive Source Sampling}

The largest difference between the means of the two normalised sampling occasions was 0.09 for TOC and 0.06 for $\delta^{15} \mathrm{~N}$ with limited differences between TN (0.01) and $\delta^{13} \mathrm{C}(0.01)$ (Figure 3). TN and $\delta^{15} \mathrm{~N}$, normalised by sampling occasions, were not normally distributed (Shapiro-Wilk test: all $p$ values $<0.001$ ), whereas there was a significant difference between sampling occasions in the variance of TOC (Levine test: $p=0.006$ ) and $\delta^{13} \mathrm{C}$ (Levine test: $p<0.001$ ). However, there were no significant differences between sampling occasions (Wilcoxon signed rank test: all $p$ values $>0.054$ ). When 
1 looking at the distributions, clear outliers were evident for TOC, TN and $\delta^{15} \mathrm{~N}$ with outliers most

2 evident for $\delta^{15} \mathrm{~N}$ resulting in the mean variance (0.17) being almost twice that of TOC and TN (both

$3 \quad 0.09)$ with no $\delta^{13} \mathrm{C}$ variance $(0.00)$.

4 Soil $\delta^{13} \mathrm{C}$ and $\delta^{15} \mathrm{~N}$ have demonstrated temporal stability in multiple studies (Fessenden and

5 Ehleringer, 2003; Kodama et al., 2008) with TN also found to be temporally persistent in cultivated

6 landscapes (Shahandeh et al., 2005). Conversely, repetitive sampling has been used to examine

7 vegetative or land-use transitions with these sediment properties indicating their potential for temporal

8 variation (Balesdent et al., 1998; Krull et al., 2005; Robson et al., 2010). The consistency of $\delta^{13} \mathrm{C}$ over

9 these sampling occasions provides further evidence that $\delta^{13} \mathrm{C}$ behaves conservatively. The outliers in

10 the TOC, TN and $\delta^{15} \mathrm{~N}$ distributions suggest the potential for temporal variation which could result

11 from the time of year for sampling (e.g. an abundance of organic matter in a particular season), the

12 antecedent sampling conditions (e.g. a wet/dry year), or the heterogeneity of sediment properties

13 within the soil. In particular, the high $\delta^{15} \mathrm{~N}$ source variance along with its potential enrichment in the

$14<2 \mu \mathrm{m}$ fraction indicates a strong potential for non-conservative behavior. Additional sampling is

15 required to confidently determine whether these sediment properties vary over time.

\section{Source Discrimination}

In Knapp Creek, grazing sources had a main distribution peak with high TOC/TN and a secondary peak with low TOC/TN (Figure 4). Gully and channel sources had low TOC/TN. Gully $\delta^{13} \mathrm{C}$ had a bimodal distribution with peaks in the channel and grazing distributions. Grazing and channel sources had distinct $\delta^{13} \mathrm{C}$ distribution peaks. The grazing $\delta^{15} \mathrm{~N}$ distribution was distinct from gully and channel sources. TOC and TN discriminated between grazing and gully sources while $\delta^{13} \mathrm{C}$ and $\delta^{15} \mathrm{~N}$ discriminated between channel and grazing sources (Table 1).

In the Upper Bremer River, gully sources had low TOC/TN compared to grazing sources with high TOC/TN while channel sources plotted in between (Figure 5). Gully and grazing sources had high $\delta^{13} \mathrm{C}$ compared to the channel sources. All $\delta^{15} \mathrm{~N}$ source distributions had overlap. $\delta^{13} \mathrm{C}$ discriminated between channel and grazing sources and between channel and gully sources (Table 1). TOC discriminated between all sources while TN discriminated between all sources except channel and grazing sources. $\delta^{15} \mathrm{~N}$ discriminated only between channel and grazing sources.

In Blackfellow Creek, $\delta^{15} \mathrm{~N}$ clearly separated channel and natural grazing sources from cultivated and grazing sources (Figure 6). Natural grazing sources had a wide range of TOC/TN concentrations. Channel sources had the lowest TOC/TN compared to grazing sources that had the highest TOC/TN with cultivated sources in between. All sources had wide $\delta^{13} \mathrm{C}$ ranges with channel and natural grazing sources plotting similarly with lower $\delta^{13} \mathrm{C}$ than cultivated and grazing sources with increasingly higher $\delta^{13} \mathrm{C} . \delta^{13} \mathrm{C}$ discriminated only between channel and grazing sources (Table 1). TOC and TN 
1 discriminated between cultivated and grazing, channel and grazing, and channel and natural grazing

2 sources. $\delta^{15} \mathrm{~N}$ discriminated between cultivated and channel sources, cultivated and natural grazing

3 sources, channel and grazing sources, and grazing and natural grazing sources.

The discrimination potential of TOC and TN varied. TOC and TN discriminated between subsoil and surface sources in Blackfellow Creek. In the Upper Bremer River, TN did not discriminate between channel and grazing sources. In Knapp Creek, neither TOC nor TN discriminated between channel and grazing sources. The lack of discrimination in Knapp Creek is likely the result of three grazing samples taken from extensive bare ground patches. These three samples had the lowest TOC and TN concentrations of all surface source samples. Additional source sampling would likely reduce the bias of these three samples resulting in significant discrimination between channel and grazing sources. In two of the three catchments TOC and/or TN significantly discriminated between surface and subsoil sources, one catchment less than anticipated based on the general analysis of TOC and TN in sediment tracing research (Carter et al., 2003; Blake et al., 2006; Owens et al., 2006; Collins et al., 2010).

Likewise, $\delta^{13} \mathrm{C}$ provided varied source discrimination. $\delta^{13} \mathrm{C}$ discriminated between gully and channel sources in the Upper Bremer River, though not in Knapp Creek. Distributions of all $\mathrm{C}_{3}$ and $\mathrm{C}_{4}$ source samples are plotted in Figure 7A. Gully source distributions from Knapp Creek and the Upper Bremer River clearly plotted within the distribution of all $\mathrm{C}_{4}$ source samples. This suggests that limited source sampling in Knapp Creek, with 2 gully samples having enriched $\mathrm{C}_{3}$ organic matter inputs, likely resulted in the lack of discrimination between channel and gully sources. Additional sampling theoretically would result in the gully source distributions becoming increasingly similar to the $\mathrm{C}_{4}$ source distribution. When channel source distributions from the Upper Bremer River and Knapp Creek are plotted with the compiled $\mathrm{C}_{3} / \mathrm{C}_{4}$ source distributions, the channel source distributions from each catchment plot within the distribution of all $\mathrm{C}_{3}$ source samples. The Knapp Creek channel distribution does overlap the intersection of $\mathrm{C}_{3}$ and $\mathrm{C}_{4}$ distributions; and, again, additional sampling would likely result in the channel source distributions becoming increasingly similar to the $\mathrm{C}_{3}$ source distribution. Although there is increasing use of $\delta^{13} \mathrm{C}$ in sediment tracing research (Fox and Papanicolaou, 2004; Fox and Papanicolaou, 2007; Collins et al., 2013), the majority of applications have been in temperate environments and have not traced sediments from $\mathrm{C}_{3}$ and $\mathrm{C}_{4}$ dominated sources in subtropical environments.

The capacity for $\delta^{15} \mathrm{~N}$ to discriminate sediment sources varied. In Blackfellow Creek the $\delta^{15} \mathrm{~N}$ discrimination of cultivated and grazing sources from channels and natural grazing sources was likely the result of differences in manure inputs. However, in this catchment $\delta^{15} \mathrm{~N}$ did not discriminate between surface and subsoil sources. In Knapp Creek and the Upper Bremer River, $\delta^{15} \mathrm{~N}$ did discriminate between grazing and channel sources though not between gully and grazing, nor gully 
1 and channel sources. The limited $\delta^{15} \mathrm{~N}$ discrimination, and therefore applicability in this region, differs

2 from the literature where $\delta^{15} \mathrm{~N}$ has been more widely modelled than $\delta^{13} \mathrm{C}$ in sediment tracing research

3 (Fox and Papanicolaou, 2008; Fox et al., 2010; Mukundan et al., 2010).

4

Owing to the variability in the source discrimination of these sediment properties we did not pool data from across the three catchments for modelling. Depending on geology and soil type, TOC and TN may be similar across the region and generally will decrease with depth in the soil profile. Making similar generalizations about $\delta^{13} \mathrm{C}$ and $\delta^{15} \mathrm{~N}$ is more challenging. For example, soil $\delta^{13} \mathrm{C}$ is directly related to the dominant vegetative regime, therefore time since clearing, land-use transitions and potentially different cropping species may impact the discrimination potential (Bird et al., 1994; Krull et al., 2005). Further, soil and sediment $\delta^{15} \mathrm{~N}$ is acknowledged as being fundamentally complex with a variety of potential nitrogen inputs and numerous internal nitrogen transformations that may fractionate the $\delta^{15} \mathrm{~N}$ of different nitrogen species (Shearer and Kohl, 1993; Evans, 2007; Finlay and Kendall, 2007). The goal of our research was to determine whether these sediment properties could be used in this region to discriminate between subsoil sources. More research is required to determine whether regional samples should be pooled or used individually in sediment tracing research.

\section{Modelling Results}

On 9 occasions lag deposits and time-integrated samplers were simultaneously sampled. The properties $\left(\delta^{13} \mathrm{C}, \delta^{15} \mathrm{~N}\right.$, TOC and $\left.\mathrm{TN}\right)$ of sediment sampled with time-integrated samplers and lag deposits for these 9 samples were not found to be significantly different (t-test: $p>0.15$ ). Olley et al., (2013a) also reported no significant difference between these sampling methods for fallout radionuclide concentrations. The mean variance of the lag deposits (2.08) was nearly 4 times greater than the time-integrated samplers $(0.55)$ and accordingly when both approaches sampled sediment simultaneously only the time-integrated samplers were modelled.

No carbon or nitrogen sediment property discriminated between gully and channel sources in Knapp Creek. We attribute this lack of discrimination to small sample size. Although there was no significant discrimination, it would be expected that with increased source sampling, $\delta^{13} \mathrm{C}$ could discriminate between gully and channel sources. Owing to the variability and enrichment of TN, TOC and $\delta^{13} \mathrm{C}$ were selected for modelling in Knapp Creek. If sediment did not plot clearly within the channel $\delta^{13} \mathrm{C}$ distribution (Figure 4), we would not have proceeded with modelling in this catchment.

Channel sources were modelled to contribute $52 \%$ of sediment sampled at both SS1 and SS2 compared to $48 \%$ from gully sources (Table 2 ). At SS3, $67 \%$ of sediments were modelled to be derived from gully sources and $33 \%$ from channel sources. At these three sites, grazing sources were modelled to contribute $<1 \%$. Elevated grazing source contributions were modelled at SS4 (13\%) and SS5 (15\%). Gully sources were modelled to contribute $<1 \%$ of sediment at SS4 and $2 \%$ at SS5. 
1 Channel erosion was modelled to contribute $87 \%$ of sediment at SS4 and $82 \%$ at SS5. Importantly,

2 gully sources did not contribute as significantly as estimated by desktop sediment budgets

$3(\sim 90 \%)($ Olley et al., 2009b) and channel bank erosion was modelled to be a significant source of

4 suspended sediment exported from Knapp Creek.

5 In the Upper Bremer River, TOC discriminated between surface and subsoil sources and $\delta^{13} \mathrm{C}$

6 discriminated between gully and channel sources. As TN did not provide discrimination in the Upper

7 Bremer River and $\delta^{15} \mathrm{~N}$ did not provide additional discrimination, $\delta^{13} \mathrm{C}$ and TOC were modelled.

8 Sediment $\delta^{13} \mathrm{C}$ was most consistent with channel sources (Figure 5). Sediment TOC plotted between

9 grazing and channel source. Some sediment samples had enriched TOC (SS4-SS6). Channel sources

10 were modelled to contribute $59 \%$ of sediment at SS1 and $>88 \%$ of sediment for the remainder of

11 stream sites (Table 3). At SS1 gully sources were modelled to contribute $30 \%$ of sediment with

12 grazing sources contributing $11 \%$. Grazing sources were modelled to contribute $12 \%$ at SS3. At the

13 remainder of stream sites, there was negligible gully or grazing sediment contributions. Similarly to

14 Knapp Creek, gully erosion did not contribute as significantly as estimated by desktop modelled

15 research ( 80\%) (Olley et al., 2010a); and channel bank erosion processes contribute significantly to

16 the suspended sediment load exported from this catchment.

In Blackfellow Creek $\delta^{15} \mathrm{~N}$ discriminated between channel and cultivated sources. Although $\delta^{13} \mathrm{C}$ discriminated between channel and grazing sources, both $\mathrm{TN}$ and $\delta^{15} \mathrm{~N}$ also discriminated between these sources making $\delta^{13} \mathrm{C}$ redundant in this catchment. Accordingly, TN and $\delta^{15} \mathrm{~N}$ were modelled. The three source end-members modelled, based on the location of sediments, were cultivated, channel, and natural grazing sources (Figure 8). $\delta^{15} \mathrm{~N}$ discriminated between sources with manure and manure derived fertilizers (cultivated and grazing) and sources with low manure inputs (channel bank and natural grazing sources)(Figure 6). Sediment sampled from the January 2010 event and the sediment traps (November 2009) had high $\delta^{15} \mathrm{~N}$ indicative of manure inputs. The remainder of events had lower $\delta^{15} \mathrm{~N}$ values indicative of channel or natural grazing sources. The May 2009 and November 2010 events were enriched in TN indicative of surface sources (Figure 6).

Sediment sampled in the January 2010 event and sediment traps (Nov. 2009) were modelled to be derived from $100 \%$ cultivated sources while cultivated sources were modelled as contributing $44 \%$ of sediment for the April 2009 event and 14\% for the April 2010 event (Table 4). Natural grazing sources were modelled as the dominant source for the May 2009 (65\%) and November 2010 (63\%) events whereas channel sources were dominant for the December 2010 (68\%) and the April 2010 events (69\%). Channel bank, natural grazing and cultivated sources each contributed significantly in different events sampled. Excluding the sediment traps, as they were not taken from the main channel of Blackfellow Creek, channel banks contributed on average $41 \%(\sigma 28 \%)$ of the sediment sampled, followed by $32 \%(\sigma 27 \%)$ from natural grazing hillslope sources and $26 \%(\sigma 38 \%)$ from cultivated 
1 sources. These results differ from the desktop modelling research (Olley et al., 2010b) by $-16 \%$ for

2 cultivated, $+9 \%$ for hillslope and $+9 \%$ for channel sources. Again, channel sources were modelled to

3 contribute more sediment than previously estimated.

\section{$4 \quad$ Implications}

5 In SEQ, the analyses of fallout radionuclides has consistently reported suspended sediments as 6 being predominantly derived from subsoil sources (Caitcheon et al., 2001; Wallbrink, 2004; Laceby, 7 2012; Olley et al., 2013b). The dominance of subsoil sources is consistent with the results of this 8 current research. Furthermore, Laceby and Olley (accepted) demonstrated that Quaternary Alluvium 9 contributes disproportionately more sediment per unit area than any other lithology in these catchments. These findings support the results of this current research that channel banks contribute significantly to the sediment exported from each of these catchments. Accordingly, management should target sediments derived from gully and channel sources in Knapp Creek and the Upper Bremer River, and sediments derived from channel and potentially cultivated sources in Blackfellow Creek.

Carbon and nitrogen sediment properties are naturally variable and inherently more dynamic than other geochemical sediment properties. The inherent variability will result in a greater likelihood of outliers in the distribution of source soil properties. Consequently, more source samples than typically used in sediment tracing research should be obtained to properly characterize the distributions of carbon and nitrogen sediment properties of source materials. Despite this limitation, this study suggests $\delta^{13} \mathrm{C}$ has potential to discriminate between $\mathrm{C}_{3}$ and $\mathrm{C}_{4}$ sediment sources with this discrimination likely being most significant in tropical and subtropical regions, or temperate regions where cultivated landscapes are dominated by $\mathrm{C}_{4}$ species. Without significant $\mathrm{C}_{3} / \mathrm{C}_{4}$ discrimination, $\delta^{13} \mathrm{C}$ will not likely be effective in sediment tracing research.

In comparison, the variation and enrichment of $\delta^{15} \mathrm{~N}$ is indicative of non-conservative behavior. Although there are multiple potential sources of $\delta^{15} \mathrm{~N}$ discrimination, there should be substantial differences (e.g. $>3 \%$ ) between $\delta^{15} \mathrm{~N}$ sources to allow for sufficient sediment source discrimination and modelling. This was evident in Blackfellow Creek where $\delta^{15} \mathrm{~N}$ clearly discriminated between sources with and without manure inputs. Moreover, there is a potential for non-conservative behavior for sources enriched in $\delta^{15} \mathrm{~N}$ from manure inputs as the enriched $\delta^{15} \mathrm{~N}$ may predominantly bound to low density particles that may be transported greater distances during events.

\section{Conclusion}

This research demonstrated that carbon and nitrogen sediment properties can be modelled to determine the sediment contributions from sources with low fallout radionuclide concentrations $\left({ }^{137} \mathrm{Cs}\right.$ 
1 and $\left.{ }^{210} \mathrm{~Pb}_{\mathrm{ex}}\right)$. In three catchments, analysis and modelling of these sediment properties determined that

2 channel bank erosion processes contributed more sediment to waterways than previously estimated.

3 Therefore channel bank erosion sources along with gully erosion sources must be effectively managed

4 to limit the supply of suspended sediment degrading Moreton Bay. This approach has the potential to

5 enhance the management of deleterious sediment loads derived from subsoil sources degrading

6 waterways worldwide.

7 Carbon and nitrogen sediment properties are more biologically labile than other geochemical

8 properties used to determine sediment provenance and researchers must be cognizant of potential

9 limitations, particularly the variance and enrichment of $\delta^{15} \mathrm{~N}$, and enrichment of TN. Importantly $\delta^{15} \mathrm{~N}$

10 and $\delta^{13} \mathrm{C}$ are concentration dependent and do not mix linearly. They should not be modelled in

11 composite approaches without being weighted by their respective TN and TOC concentrations. New

12 mixing models must be developed in order to simultaneously model the concentration dependency of

13 these isotopes with fallout radionuclides and geochemical sediment properties or models from the

14 isotopic literature must be adopted for sediment tracing research.

\section{Acknowledgements}

16 David Sternberg, Adam Kerezy, Nat Daley, Tanya Ellison, and Alexandra Garzon-Garcia are

17 acknowledged for their assistance with field work and Brian Fry for lively isotopic discussions.

18 Further we would like to acknowledge the Healthy Country Project catchment coordinators Brad

19 Rickard, Fiona Bengtssoon, and Amanda Bland for their support along with the landholders who

20 granted us access to their properties. Funding was provided by the Healthy Country Project, an

21 initiative of the Queensland State Government, the eWater Cooperative Research Center, Griffith

22 University's School of Environment and Australian Rivers Institute. Finally we would like to thank

23 two anonymous reviewers for their insightful comments and feedback. 
Amundson R, Austin AT, Schuur EAG, Yoo K, Matzek V, Kendall C, Uebersax A, Brenner D, Baisden WT. 2003. Global patterns of the isotopic composition of soil and plant nitrogen. Global Biogeochem. Cycles, 17: 1031. DOI: 10.1029/2002gb001903.

Balesdent J, Besnard E, Arrouays D, Chenu C. 1998. The dynamics of carbon in particle-size fractions of soil in a forest-cultivation sequence. Plant and Soil, 201: 49-57. DOI: 0.1023/A:1004337314970.

Balesdent J, Mariotti A, Guillet B. 1987. Natural ${ }^{13} \mathrm{C}$ abundance as a tracer for studies of soil organic matter dynamics. Soil Biology and Biochemistry, 19: 25-30.

Bellanger B, Huon S, Velasquez F, Valles V, Girardin C, Mariotti A. 2004. Monitoring soil organic carbon erosion with $\mathrm{d}^{13} \mathrm{C}$ and $\mathrm{d}^{15} \mathrm{~N}$ on experimental field plots in the Venezuelan Andes. Catena, 58: 125-150.

Bilotta GS, Brazier RE. 2008. Understanding the influence of suspended solids on water quality and aquatic biota. Water Research, 42: 2849-2861. DOI: http://dx.doi.org/10.1016/j.watres.2008.03.018.

Bird MI, Giresse P, Chivas AR. 1994. Effect of forest and savanna vegetation on the carbon-isotope composition of sediments from the Sanaga River, Cameroon. Limnol Oceanogr, 39: 18451854.

Blake W, Walsh R, Sayer A, Bidin K. 2006. Quantifying fine-sediment sources in primary and selectively logged rainforest catchments using geochemical tracers. Water, Air, \& Soil Pollution: Focus, 6: 615-623.

Blake WH, Ficken KJ, Taylor P, Russell MA, Walling DE. 2012. Tracing crop-specific sediment sources in agricultural catchments. Geomorphology, 139-140. DOI: 10.1016/j.geomorph.2011.10.036.

Bunn SE, Abal EG, Greenfield PF, Tarte DM. 2007. Making the connections between healthy waterways and healthy catchments. Water science and Technology: water supply, 7: 224-232.

Caitcheon G, Olley J, Pantus F, Hancock GR, Leslie C. 2012. The dominant erosion processes supplying fine sediment to three major rivers in tropical Australia, the Daly (NT), Mitchell (Q1d) and Cloncurry (Qld) Rivers. Geomorphology, 151-152: 188-195.

Caitcheon G, Prosser I, Wallbrink P, Douglas G, Olley J, Hughes A, Hancock G, Scott A. 2001. Sediment delivery from Moreton Bay's main tributaries: a multifaceted approach to identifying sediment sources. In: Third Australian Stream Management Conference, Rutherfurd I, Sheldon F, Brierley G, Kenyon C (eds.) Cooperative Research Centre for Catchment Hydrology, Melbourne, pp: 103-107.

Carter J, Owens PN, Walling DE, Leeks GJL. 2003. Fingerprinting suspended sediment sources in a large urban river system. Science of The Total Environment, 314: 513-534. DOI: Doi 10.1016/S0048-9697(03)00071-8.

Clark EH. 1985. The off-site costs of soil erosion. Journal of Soil and Water Conservation, 40: 19-22.

Collins A, Zhang Y, Hickinbotham R, Bailey G, Darlington S, Grenfell S, Evans R, Blackwell M. 2013. Contemporary fine-grained bed sediment sources across the River Wensum Demonstration Test Catchment, UK. Hydrological Processes, 27: 857-884.

Collins AL, Naden PS, Sear DA, Jones JI, Foster IDL, Morrow K. 2011. Sediment targets for informing river catchment management: international experience and prospects. Hydrological processes, 25: 2112-2129. DOI: 10.1002/hyp.7965.

Collins AL, Walling DE, McMellin GK, Zhang Y, Gray J, McGonigle D, Cherrington R. 2010. A preliminary investigation of the efficacy of riparian fencing schemes for reducing contributions from eroding channel banks to the siltation of salmonid spawning gravels across the south west UK. Journal of Environmental Management, 91: 1341-1349.

Collins AL, Zhang Y, McChesney D, Walling DE, Haley SM, Smith P. 2012. Sediment source tracing in a lowland agricultural catchment in southern England using a modified procedure combining statistical analysis and numerical modelling. Science of The Total Environment, 414: 301-317. DOI: 10.1016/j.scitotenv.2011.10.062. 
Douglas G, Palmer M, Caitcheon G. 2003. The provenance of sediments in Moreton Bay, Australia: a synthesis of major, trace element and $\mathrm{Sr}-\mathrm{Nd}-\mathrm{Pb}$ isotopic geochemistry, modelling and landscape analysis. Hydrobiologia, 494: 145-152.

Dytham C. 2003. Choosing and Using Statistics, A Biologist's Guide. 2nd Edition Edn., Blackwell Publishing.

Evans RD. 2007. Soil nitrogen isotope composition. In: Stable Isotopes in Ecology and Environmental Science, Michener R, Lajtha K (eds.) Blackwell Publishing, pp: 83-98.

Fessenden JE, Ehleringer JR. 2003. Temporal variation in $\mathrm{d}^{13} \mathrm{C}$ of ecosystem respiration in the Pacific Northwest: links to moisture stress. Oecologia, 136: 129-136. DOI: 10.1007/s00442-0031260-1.

Finlay JC, Kendall C. 2007. Stable isotope tracing of temporal and spatial variability in organic matter sources to freshwater ecosystems. In: Stable Isotopes in Ecology and Environmental Science, Michener R, Lajtha K (eds.) Blackwell, Malden, MA, pp: 283-333.

Fox J, Papanicolaou AN. 2004. Tracing Sediment Sources by Using Stable Carbon and Nitrogen Isotopes: An Exploratory Research. In: IIHR Technical Report, Iowa Institute of Hydraulic Research, The University of Iowa, pp: 1-15.

Fox JF. 2005. Fingerprinting using biogeochemical tracers to investigate watershed processes. Ph.D. Dissertation. Civil and Environmental Engineering. The University of Iowa. Iowa City.

Fox JF, Davis CM, Martin DK. 2010. Sediment source assessment in a lowland watershed using nitrogen stable isotopes. Journal of the American Water Resources Association, 46: 11921204. DOI: $10.1111 /$ j.1752-1688.2010.00485.x.

Fox JF, Papanicolaou AN. 2007. The use of carbon and nitrogen isotopes to study watershed erosion processes. Journal of the American Water Resources Association, 43: 1047-1064.

Fox JF, Papanicolaou AN. 2008. Application of the spatial distribution of nitrogen stable isotopes for sediment tracing at the watershed scale. Journal of Hydrology, 358: 46-55. DOI: DOI 10.1016/j.jhydrol.2008.05.032.

Fry B. 2006. Stable Isotope Ecology. Springer. New York.

Gibbs M. 2008. Identifying source soils in contemporary estuarine sediments: A new compoundspecific isotope method. Estuaries and Coasts, 31: 344-359. DOI: 10.1007/s12237-007-90129.

Hancock GJ, Revill AT. 2013. Erosion source discrimination in a rural Australian catchment using compound-specific isotope analysis (CSIA). Hydrological Processes, 27: 923-932. DOI: 10.1002/hyp.9466.

Hattersley PW. 1983. The distribution of $\mathrm{C}_{3}$ and $\mathrm{C}_{4}$ grasses in Australia in relation to climate. Oecologia, 57: 113-128. DOI: 10.1007/bf00379569.

Juracek KE, Ziegler AC. 2009. Estimation of sediment sources using selected chemical tracers in the Perry lake basin, Kansas, USA. International Journal of Sediment Research, 24: 108-125.

Karamanos RE, Rennie DA. 1980. Changes in natural ${ }^{15} \mathrm{~N}$ abundance associated with pedogenic processes in soil. II. Changes on different slope positions. Canadian Journal of Soil Science, 60: $365-372$. DOI: $10.4141 /$ cjss80-039.

Kennedy P, Kennedy H, Papadimitriou S. 2005. The effect of acidification on the determination of organic carbon, total nitrogen and their stable isotopic composition in algae and marine sediment. Rapid Communications in Mass Spectrometry, 19: 1063-1068. DOI: $10.1002 / \mathrm{rcm} .1889$.

Kodama N, Barnard R, Salmon Y, Weston C, Ferrio J, Holst J, Werner R, Saurer M, Rennenberg H, Buchmann N, Gessler A. 2008. Temporal dynamics of the carbon isotope composition in a Pinus sylvestris stand: from newly assimilated organic carbon to respired carbon dioxide. Oecologia, 156: 737-750. DOI: 10.1007/s00442-008-1030-1.

Koiter A, Owens P, Petticrew E, Lobb D. 2013. The behavioural characteristics of sediment properties and their implications for sediment fingerprinting as an approach for identifying sediment sources in river basins. Earth-Science Reviews, 125: 24-42.

Krull E, Skjemstad JO, Burrows WH, Bray SG, Wynn JG, Bol R, Spouncer L, Harms B. 2005. Recent vegetation changes in central Queensland, Australia: Evidence from $\mathrm{d}^{13} \mathrm{C}$ and ${ }^{14} \mathrm{C}$ analyses of soil organic matter. Geoderma, 126: 241-259. 
Laceby JP. 2012. The Provenance of Sediment in Three Rural Catchments in South East Queensland, Australia. In: Science, Environment, Engineering and Technology, Griffith School of Environment., Griffith University.

Laceby JP, Olley J. accepted. An examination of geochemical modelling approaches to tracing sediment sources incorporating distribution mixing and elemental correlations. Hydrological processes.

Motha JA, Wallbrink PJ, Hairsine PB, Grayson RB. 2002. Tracer properties of eroded sediment and source material. Hydrological Processes, 16: 1983-2000.

Mukundan R, Radcliffe DE, Ritchie JC, Risse LM, Mckinley RA. 2010. Sediment fingerprinting to determine the source of suspended sediment in a southern piedmont stream. Journal of Environmental Quality, 39: 1328-1337.

Natelhoffer KJ, Fry B. 1988. Controls on natural nitrogen-15 and carbon-13 abundances in forest soil organic matter. Soil Science Society of America Journal, 52: 1633-1640.

Olley J, Brooks A, Spencer J, Pietsch T, Borombovits D. 2013a. Subsoil erosion dominates the supply of fine sediment to rivers draining into Princess Charlotte Bay, Australia. Journal of Environmental Radioactivity, 124: 121-129. DOI: http://dx.doi.org/10.1016/j.jenvrad.2013.04.010.

Olley J, Burton J, Smolders K, Pantus F, Pietsch T. 2013b. The application of fallout radionuclides to determine the dominant erosion process in water supply catchments of subtropical South-east Queensland, Australia. Hydrological Processes, 27: 885-895. DOI: 10.1002/hyp.9422.

Olley J, Caitcheon G. 2000. Major element chemistry of sediments from the Darling-Barwon river and its tributaries: implications for sediment and phosphorus sources. Hydrological Processes, 14: $1159-1175$.

Olley J, McMahon J, Ward D, Saxton N, Pietsch T, Laceby JP, Bland A, Rose CW, Pantus F. 2010a. Rehabilitation Priorities Bremer Focal Area. Healthy Waterways Partnership, Brisbane.

Olley J, Sheldon F, Hadwen W, Fellows C, Saxton N, McMahon J, Laceby JP, Pietsch T, Negus P. 2009a. Monitoring and evaluation of restoration activities in three SEQ focal catchments. Healthy Waterways Partnership, Brisbane.

Olley J, Ward D, McMahon J, Saxton N, Pietsch T, Laceby JP, Bengtsson F, Rose CW, Pantus F. 2010b. Rehabilitation Priorities Lockyer Focal Area. Healthy Waterways Partnership, Brisbane.

Olley J, Ward D, Pietsch T, McMahon J, Laceby JP, Saxton N, Rickard B, Rose CW, Pantus F. 2009b. Rehabilitation priorities Knapp Creek. Healthy Waterways Partnership, Brisbane.

Olley J, Young B, Caitcheon G, Hughes A, Prosser I, Croke B, Beavis S, Page D, Wasson R. 2003. Sources of sediment and nutrients in the Wingecarribee Catchment. CSIRO Land and Water, Canberra.

Olley JM, Caitcheon GG, Hancock G, Wallbrink PJ. 2001. Tracing and dating techniques for sediment and associated substances. CSIRO Land and Water, Canberra.

Owens PN, Blake WH, Petticrew EL. 2006. Changes in Sediment Sources Following Wildfire in Mountainous Terrain: A Paired-Catchment Approach, British Columbia, Canada. In: The Interactions Between Sediments and Water, Kronvang B, Faganeli J, Ogrinc N (eds.) Springer Netherlands, pp: 273-281.

Phillips D, Koch P. 2002. Incorporating concentration dependence in stable isotope mixing models. Oecologia, 130: 114-125. DOI: $10.1007 / \mathrm{s} 004420100786$.

Phillips DL, Gregg JW. 2003. Source partitioning using stable isotopes: coping with too many sources. Oecologia, 136: 261-269. DOI: 10.1007/s00442-003-1218-3.

Phillips JM, Russell MA, Walling DE. 2000. Time-integrated sampling of fluvial suspended sediment: a simple methodology for small catchments. Hydrological Processes, 14: 25892602.

Razali NM, Wah YB. 2011. Power comparisons of Shapiro-Wilk, Kolmogorov-Smirnov, Lilliefors and Anderson-Darling tests. Journal of Statistical Modeling and Analytics, 2: 21-33.

Robson TM, Baptist F, Clément J-C, Lavorel S. 2010. Land use in subalpine grasslands affects nitrogen cycling via changes in plant community and soil microbial uptake dynamics. Journal of Ecology, 98: 62-73. DOI: 10.1111/j.1365-2745.2009.01609.x. 
Saxton NE, Olley JM, Smith S, Ward DP, Rose CW. 2012. Gully erosion in sub-tropical south-east Queensland, Australia. Geomorphology, 173-174: 80-87. DOI: 10.1016/j.geomorph.2012.05.030.

Schimel DS. 1993. Theory and Application of Tracers. Academic Press, Inc., San Diego.

Shahandeh H, Wright AL, Hons FM, Lascano RJ. 2005. Spatial and temporal variation of soil nitrogen parameters related to soil texture and corn yield. Agron. J., 97: 772-782. DOI: 10.2134/agronj2004.0287.

Shearer G, Kohl DH. 1993. Natural Abundance of ${ }^{15} \mathrm{~N}$ : Fractional Contribution of Two Sources to a Common Sink and Use of Isotope Discrimination. In: Nitrogen Isotope Techniques, Knowles R, Blackburn H (eds.) Academic Press, Inc.

Sheather S, J. 2004. Density estimation. Statistical Science, 19: 588-597.

Silverman BW. 1952. Density estimation for statistics and data analysis. Chapman \& Hall/CRC Press. Boca Raton, Florida.

Smith HG, Blake WH. 2014. Sediment fingerprinting in agricultural catchments: A critical reexamination of source discrimination and data corrections. Geomorphology, 204: 177-191.

Stemmer M, Von Lützow M, Kandeler E, Pichlmayer F, Gerzabek MH. 1999. The effect of maize straw placement on mineralization of $\mathrm{C}$ and $\mathrm{N}$ in soil particle size fractions. European Journal of Soil Science, 50: 73-85. DOI: 10.1046/j.1365-2389.1999.00204.x.

Wallbrink PJ. 2004. Quantifying the erosion processes and land-uses which dominate fine sediment supply to Moreton Bay, Southeast Queensland, Australia. Journal of Environmental Radioactivity, 76.

Wallbrink PJ, Murray AS, Olley JM, Olive LJ. 1998. Determining sources and transit times of suspended sediment in the Murrumbidgee River, New South Wales, Australia, using fallout ${ }^{137} \mathrm{Cs}$ and ${ }^{210} \mathrm{~Pb}$. Water Resour. Res., 34: 879-887. DOI: 10.1029/97wr03471.

Walling DE. 2005. Tracing suspended sediment sources in catchments and river systems. Science of The Total Environment, 344: 159-184.

Walling DE, Owens PN, Leeks GJL. 1999. Fingerprinting suspended sediment sources in the catchment of the River Ouse, Yorkshire, UK. Hydrological processes, 13: 955-975.

Walling DE, Woodward JC. 1995. Tracing sources of suspended sediment in river basins - a casestudy of the River Culm, Devon, Uk. Marine and Freshwater Research, 46: 327-336.

Walling DE, Woodward JC, Nicholas AP. 1993. A multi-parameter approach to fingerprinting suspended-sediment sources. In: Tracers in Hydrology, Peters NE, Hoehn E, Leibundgut C, Tase N, Walling DE (eds.) IAHS Press, Centre for Ecology and Hydrology, Wallingford, Oxfordshire, UK, pp: 10.

Wilkinson S, Hancock G, Bartley R, Hawdon A, Keen R. 2013. Using sediment tracing to assess processes and spatial patterns of erosion in grazed rangelands, Burdekin River basin, Australia. Agriculture, Ecosystems \& Environment, 180: 90-102.

Wynn JG, Bird MI, Wong VNL. 2005. Rayleigh distillation and the depth profile of ${ }^{13} \mathrm{C} /{ }^{12} \mathrm{C}$ ratios of soil organic carbon from soils of disparate texture in Iron Range National Park, Far North Queensland, Australia. Geochim Cosmochim Ac, 69: 1961-1973. DOI: 10.1016/j.gca.2004.09.003. 
Table 1. Mann-Whitney U-test results and $p$ values (minor figures) with significant results shaded $(<0.05)$.

\begin{tabular}{|c|c|c|c|c|c|}
\hline Catchment & Source & TOC & $\mathbf{T N}$ & $\delta^{13} \mathrm{C}$ & $\delta^{15} \mathbf{N}$ \\
\hline \multirow[t]{6}{*}{ Knapp Creek } & \multirow[t]{2}{*}{ Channel vs Grazing } & 1.61 & 1.599 & 3.845 & 2.465 \\
\hline & & 0.107 & 0.11 & $<0.001$ & 0.014 \\
\hline & \multirow[t]{2}{*}{ Channel vs Gully } & 1.86 & 1.553 & 1.587 & 0.363 \\
\hline & & 0.063 & 0.12 & 0.113 & 0.717 \\
\hline & \multirow[t]{2}{*}{ Grazing vs Gully } & 2.178 & 2.198 & 1.95 & 1.859 \\
\hline & & 0.029 & 0.028 & 0.051 & 0.063 \\
\hline \multirow{6}{*}{ Upper Bremer River } & \multirow[t]{2}{*}{ Channel vs Grazing } & 2.393 & 2.233 & 4.694 & 2.145 \\
\hline & & 0.017 & 0.26 & $<0.001$ & 0.032 \\
\hline & \multirow[t]{2}{*}{ Channel vs Gully } & 3.724 & 3.635 & 2.908 & 0.243 \\
\hline & & $<0.001$ & $<0.001$ & 0.004 & 0.808 \\
\hline & \multirow[t]{2}{*}{ Grazing vs Gully } & 3.428 & 3.541 & 1.579 & 1.142 \\
\hline & & 0.001 & $<0.001$ & 0.114 & 0.254 \\
\hline \multirow{12}{*}{ Blackfellow Creek } & \multirow[t]{2}{*}{ Cultivated vs Channel } & 1.376 & 1.808 & 1.397 & 4.214 \\
\hline & & 0.169 & 0.071 & 0.162 & $<0.001$ \\
\hline & \multirow[t]{2}{*}{ Cultivated vs Grazing } & 3.807 & 3.767 & 1.854 & 0.219 \\
\hline & & $<0.001$ & $<0.001$ & 0.064 & 0.827 \\
\hline & \multirow[t]{2}{*}{ Cultivated vs Natural Grazing } & 1.86 & 1.541 & 1.28 & 3.382 \\
\hline & & 0.063 & 0.123 & 0.201 & 0.001 \\
\hline & \multirow[t]{2}{*}{ Channel vs Grazing } & 3.884 & 3.943 & 2.247 & 4.157 \\
\hline & & $<0.001$ & $<0.001$ & 0.025 & $<0.001$ \\
\hline & \multirow[t]{2}{*}{ Channel vs Natural Grazing } & 2.104 & 2.11 & 0.156 & 1.169 \\
\hline & & 0.035 & 0.035 & 0.876 & 2.42 \\
\hline & \multirow[t]{2}{*}{ Grazing vs Natural Grazing } & 0.292 & 1.000 & 1.722 & .238 \\
\hline & & 0.771 & 0.317 & 0.085 & 0.001 \\
\hline
\end{tabular}

1

2 
Table 2. Knapp Creek modelling results reporting the median source contribution from 2500 modelling runs (top line) and the MAD (minor figures on second row) for channel $(\mathrm{CH})$, grazing (GR) and gully $(\mathrm{GU})$ sources along with the mixing model difference (MMD) from Eq. 5.

\begin{tabular}{cccccccc}
\hline Site & MMD & CH & CH $~$ & GR & GR $~$ & GU & GU $~$ \\
\hline SS1 & 0.309 & $52 \%$ & $2 \%$ & $0 \%$ & $2 \%$ & $48 \%$ & $2 \%$ \\
& 0.054 & $8 \%$ & $2 \%$ & $4 \%$ & $2 \%$ & $10 \%$ & $3 \%$ \\
\hline SS2 & 0.314 & $52 \%$ & $2 \%$ & $1 \%$ & $1 \%$ & $48 \%$ & $1 \%$ \\
& 0.057 & $8 \%$ & $2 \%$ & $4 \%$ & $2 \%$ & $10 \%$ & $2 \%$ \\
\hline SS3 & 0.376 & $33 \%$ & $1 \%$ & $0 \%$ & $1 \%$ & $67 \%$ & $8 \%$ \\
& 0.100 & $11 \%$ & $2 \%$ & $4 \%$ & $2 \%$ & $14 \%$ & $3 \%$ \\
\hline SS4 & 0.273 & $87 \%$ & $2 \%$ & $13 \%$ & $1 \%$ & $0 \%$ & $15 \%$ \\
& 0.019 & $5 \%$ & $2 \%$ & $4 \%$ & $2 \%$ & $2 \%$ & $1 \%$ \\
\hline SS5 & 0.260 & $82 \%$ & $2 \%$ & $15 \%$ & $1 \%$ & $2 \%$ & $9 \%$ \\
& 0.020 & $6 \%$ & $2 \%$ & $4 \%$ & $2 \%$ & $3 \%$ & $2 \%$ \\
\hline
\end{tabular}

1 
Table 3. Upper Bremer River modelling results reporting the median source contribution from 2500 modelling runs (top line) and the MAD (minor figures on second row) for channel $(\mathrm{CH})$, grazing (GR) and gully $(\mathrm{GU})$ along with the mixing model difference (MMD) from Eq. 5.

\begin{tabular}{llllllll}
\hline Site & MMD & CH & CH $~$ & GR & GR $~$ & GU & GU $~$ \\
\hline SS1 & 0.248 & $59 \%$ & $1 \%$ & $11 \%$ & $2 \%$ & $30 \%$ & $4 \%$ \\
& 0.032 & $7 \%$ & $2 \%$ & $4 \%$ & $2 \%$ & $6 \%$ & $2 \%$ \\
\hline SS2 & 0.289 & $98 \%$ & $1 \%$ & $2 \%$ & $2 \%$ & $0 \%$ & $14 \%$ \\
& 0.012 & $5 \%$ & $1 \%$ & $4 \%$ & $2 \%$ & $1 \%$ & $1 \%$ \\
\hline SS3 & 0.293 & $88 \%$ & $2 \%$ & $12 \%$ & $3 \%$ & $0 \%$ & $11 \%$ \\
& 0.012 & $5 \%$ & $2 \%$ & $4 \%$ & $2 \%$ & $1 \%$ & $2 \%$ \\
\hline SS4 & 0.354 & $100 \%$ & $1 \%$ & $0 \%$ & $13 \%$ & $0 \%$ & $15 \%$ \\
& 0.012 & $4 \%$ & $1 \%$ & $3 \%$ & $1 \%$ & $1 \%$ & $1 \%$ \\
\hline SS5 & 0.308 & $100 \%$ & $1 \%$ & $0 \%$ & $9 \%$ & $0 \%$ & $15 \%$ \\
& 0.013 & $5 \%$ & $1 \%$ & $4 \%$ & $1 \%$ & $1 \%$ & $1 \%$ \\
\hline SS6 & 0.451 & $100 \%$ & $1 \%$ & $0 \%$ & $15 \%$ & $0 \%$ & $15 \%$ \\
& 0.019 & $4 \%$ & $1 \%$ & $3 \%$ & $1 \%$ & $1 \%$ & $1 \%$ \\
\hline
\end{tabular}

1

2 
Table 4. Blackfellow Creek modelling results reporting the median source contribution from 2500 modelling runs (top line) and the MAD (minor figures on second row) for channel $(\mathrm{CH})$, natural grazing (NG) and cultivated (CU) sources along with the mixing model difference (MMD) from Eq. 5.

\begin{tabular}{llllllll}
\hline Site & MMD & $\mathbf{C H}$ & $\mathbf{C H} \sigma$ & $\mathbf{C U}$ & $\mathbf{C U} \boldsymbol{\sigma}$ & NG & NG $\sigma$ \\
\hline April 2009 & 0.416 & $38 \%$ & $2 \%$ & $44 \%$ & $1 \%$ & $18 \%$ & $2 \%$ \\
& 0.044 & $7 \%$ & $3 \%$ & $6 \%$ & $2 \%$ & $5 \%$ & $2 \%$ \\
\hline May 2009 & 0.609 & $35 \%$ & $3 \%$ & $0 \%$ & $15 \%$ & $65 \%$ & $2 \%$ \\
& 0.058 & $9 \%$ & $2 \%$ & $3 \%$ & $1 \%$ & $11 \%$ & $2 \%$ \\
\hline Nov. 2009 & 0.634 & $0 \%$ & $1 \%$ & $100 \%$ & $15 \%$ & $0 \%$ & $1 \%$ \\
& 0.112 & $10 \%$ & $2 \%$ & $11 \%$ & $1 \%$ & $1 \%$ & $2 \%$ \\
\hline Jan. 2010 & 0.643 & $0 \%$ & $1 \%$ & $100 \%$ & $15 \%$ & $0 \%$ & $1 \%$ \\
& 0.090 & $8 \%$ & $2 \%$ & $9 \%$ & $1 \%$ & $1 \%$ & $1 \%$ \\
\hline April 210 & 0.604 & $69 \%$ & $15 \%$ & $14 \%$ & $2 \%$ & $16 \%$ & $1 \%$ \\
& 0.061 & $7 \%$ & $2 \%$ & $5 \%$ & $2 \%$ & $5 \%$ & $3 \%$ \\
\hline \multirow{2}{*}{ Nov. 2010 } & 0.570 & $37 \%$ & $1 \%$ & $0 \%$ & $15 \%$ & $63 \%$ & $1 \%$ \\
& 0.056 & $9 \%$ & $2 \%$ & $4 \%$ & $1 \%$ & $11 \%$ & $2 \%$ \\
\hline Dec. 2010 & 0.887 & $68 \%$ & $15 \%$ & $0 \%$ & $1 \%$ & $32 \%$ & $1 \%$ \\
& 0.107 & $6 \%$ & $2 \%$ & $3 \%$ & $2 \%$ & $6 \%$ & $2 \%$ \\
\hline
\end{tabular}

1

\section{List of Figures (and captions):}

3 Figure 1. Sampling region (Inset: SEQ) and Blackfellow Creek, the Upper Bremer River, and Knapp

4 Creek sampling locations.

5 Figure 2. Distributions of the normalised particle size fractions for all nitrogen and carbon sediment 6 properties. Points under the distributions are the normalised samples colour coded to particle size 7 fraction ( $h$ parameters were: TOC $0.294, \mathrm{TN} 0.388, \delta^{13} \mathrm{C} 0.013, \delta^{15} \mathrm{~N} 0.105$ ).

8 Figure 3. Distributions for each normalised sampling occasion for all nitrogen and carbon sediment 9 properties. Points under the distributions are the normalised samples colour coded to sampling 10 occasion ( $h$ parameters were: TOC 0.092 , TN $0.040, \delta^{13} \mathrm{C} 0.014, \delta^{15} \mathrm{~N} 0.112$ ).

11 Figure 4. Knapp Creek source distributions and sediment samples with points under the distributions 12 being colour coded source samples ( $h$ parameters: TOC 0.578 , TN $0.046, \delta^{13} \mathrm{C} 0.934$, and $\delta^{15} \mathrm{~N} 0.602$ ).

Figure 5. Upper Bremer River source distributions and sediment samples with points under the distributions being the colour coded source samples ( $h$ parameters were: TOC 0.282 , TN $0.026, \delta^{13} \mathrm{C}$ 150.692 , and $\left.\delta^{15} \mathrm{~N} 0.953\right)$.

Figure 6. Blackfellow Creek source distributions with points under the distributions being the colour coded source samples ( $h$ parameters were: TOC 0.954 , TN $0.083, \delta^{13} \mathrm{C} 1.002$, and $\delta^{15} \mathrm{~N} 0.872$ ).

18 Figure 7. Distributions of all $\mathrm{C}_{3}$ and $\mathrm{C}_{4}$ vegetative samples with gully (A) and channel (B) source 19 samples from Knapp Creek (KK) and the Upper Bremer River (BR) $\left(\mathrm{C}_{3} / \mathrm{C}_{4} h\right.$ parameter: 0.860$) . \mathrm{C}_{3}$ samples (top black circles below distributions) include channel $(n$ 45) and natural grazing $(n 6)$ sources. $\mathrm{C}_{4}$ samples (dark red circles) include grazing ( $\left.n 43\right)$ and gully ( $n$ 13) sources.

22 Figure 8. Blackfellow Creek $\delta^{15} \mathrm{~N}-\mathrm{TN} \%$ results for in-stream and source samples with circles drawn in to estimate source ranges. 

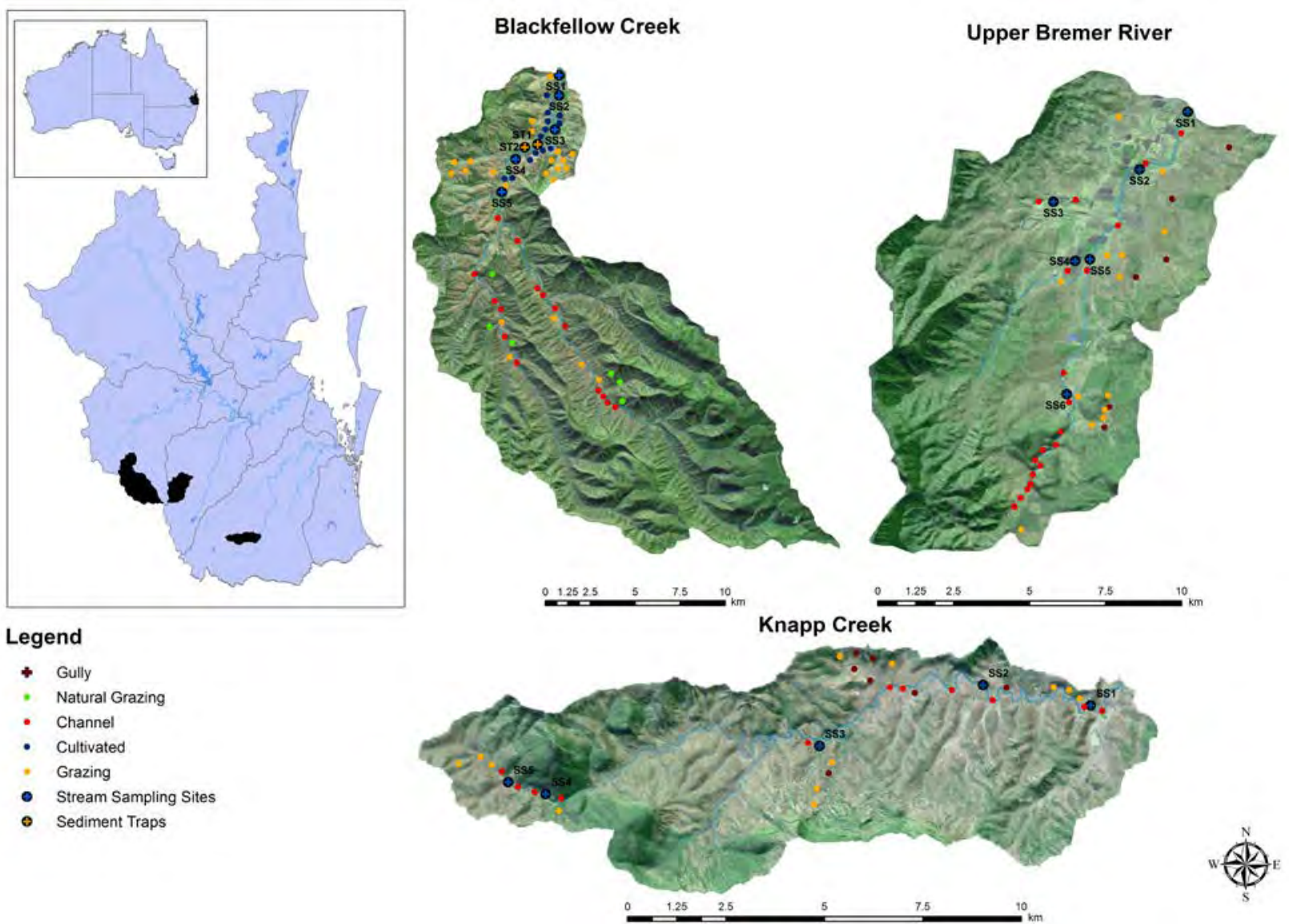

+ Gully

- Natural Grazing

- Channel

- Cultivated

- Grazing

- Stream Sampling Sites

- Sediment Traps 

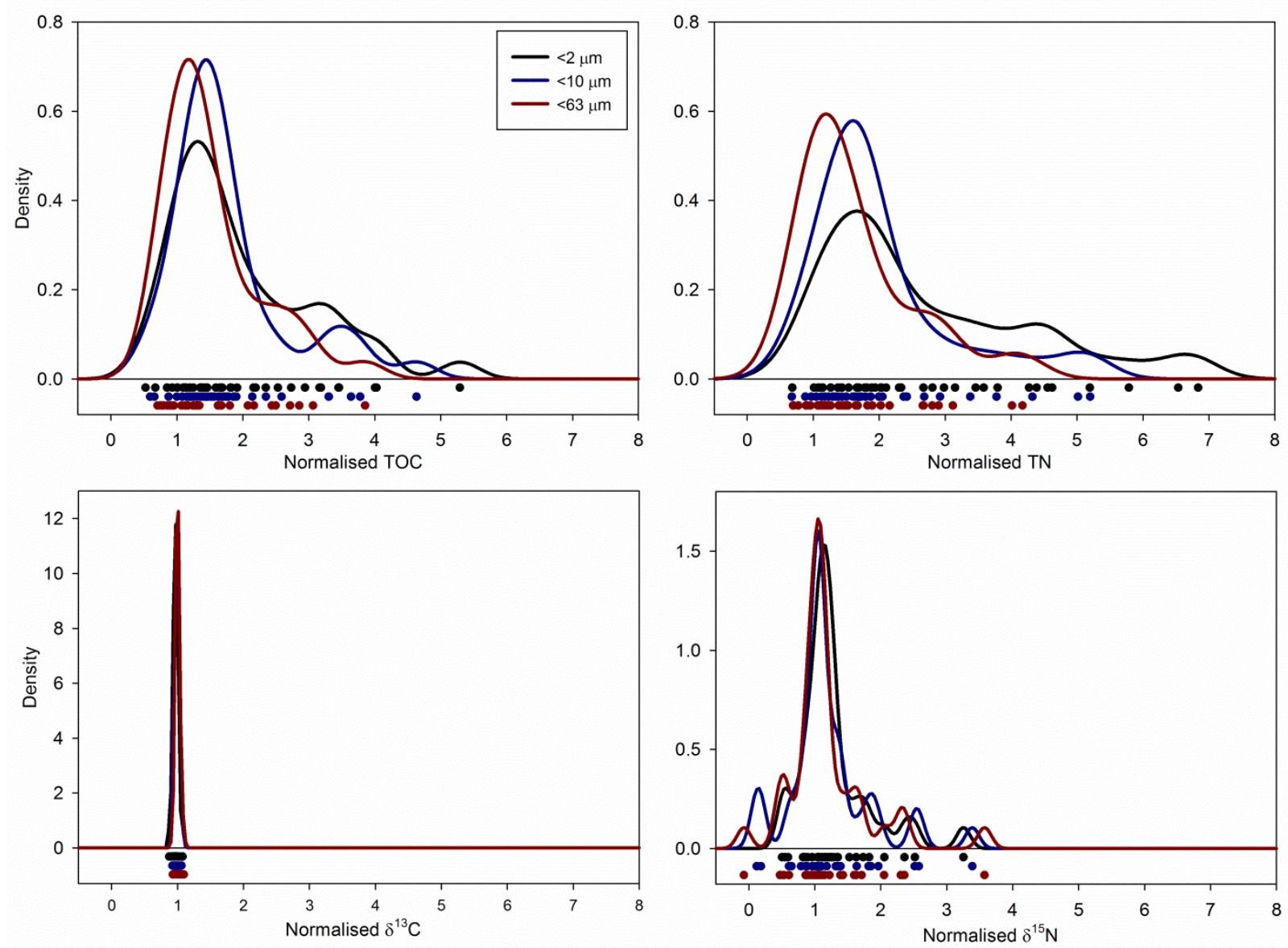

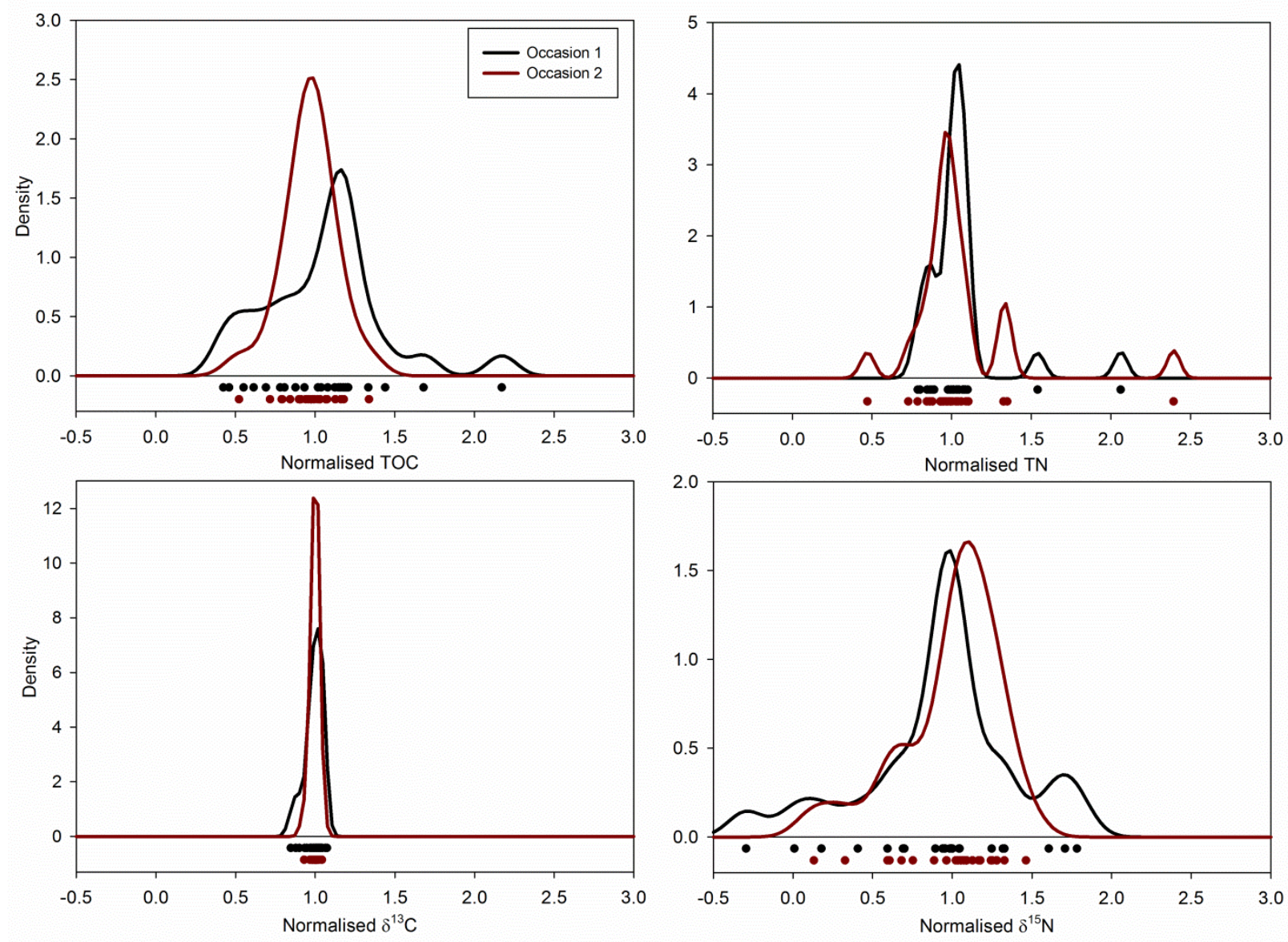

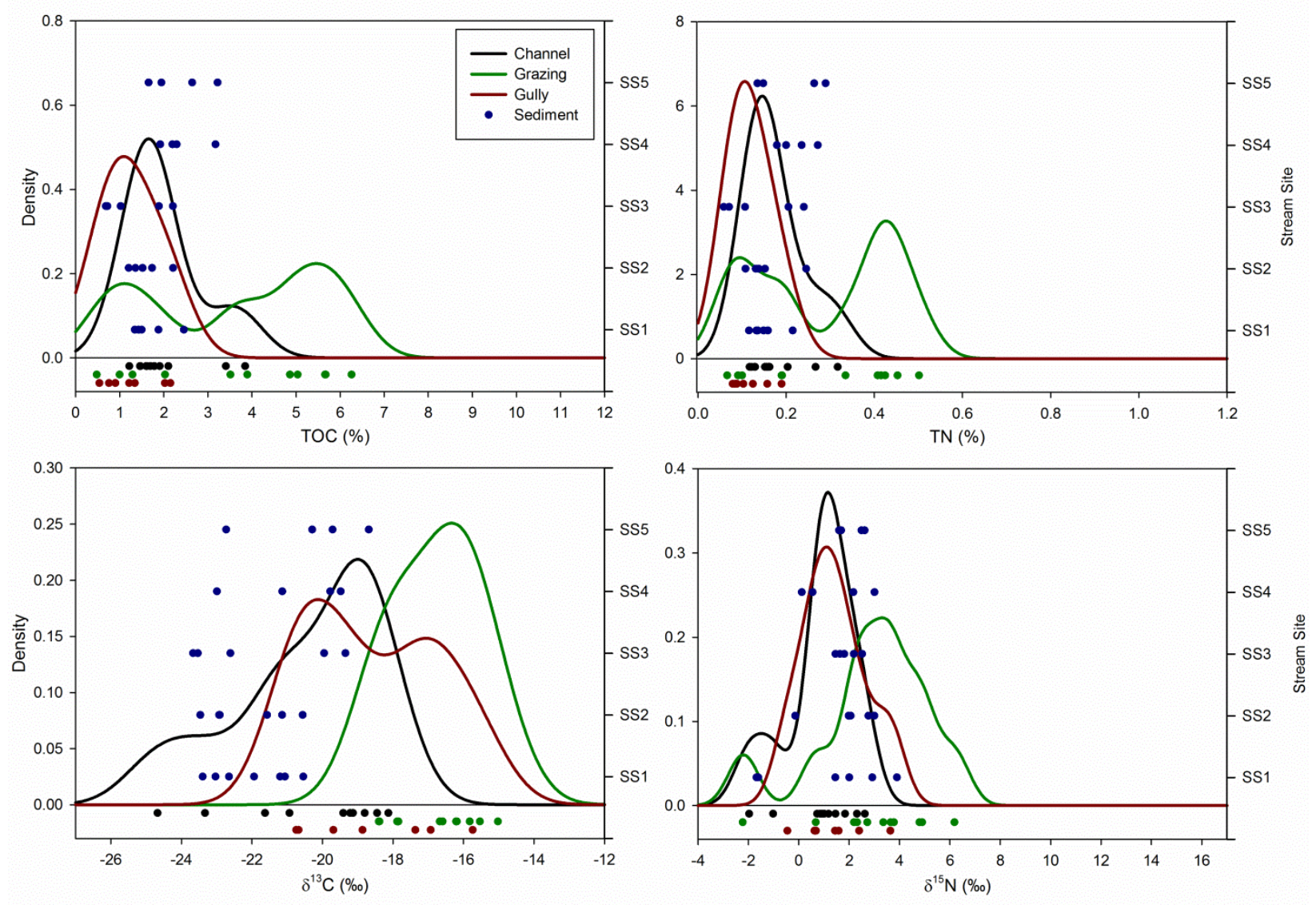

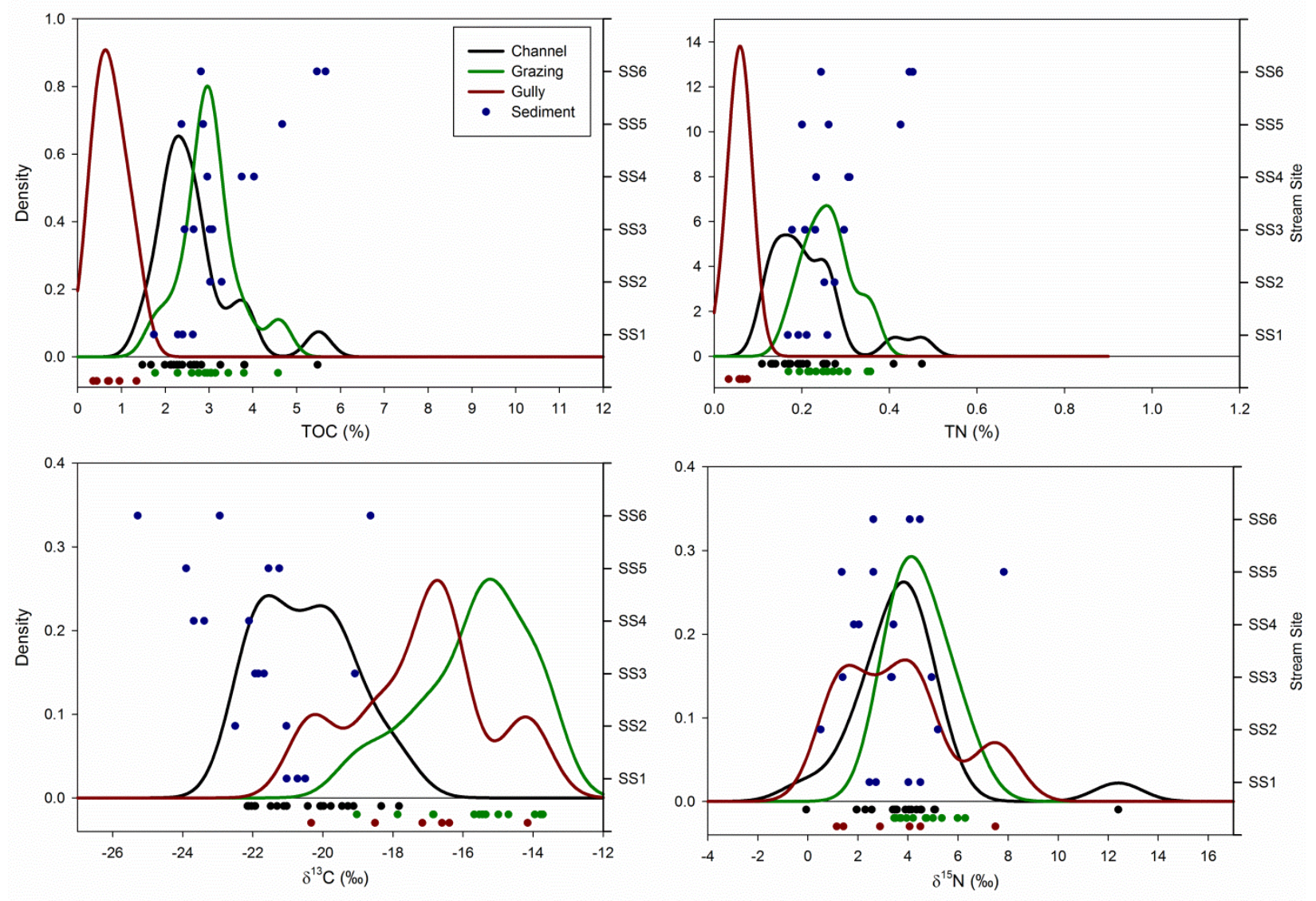

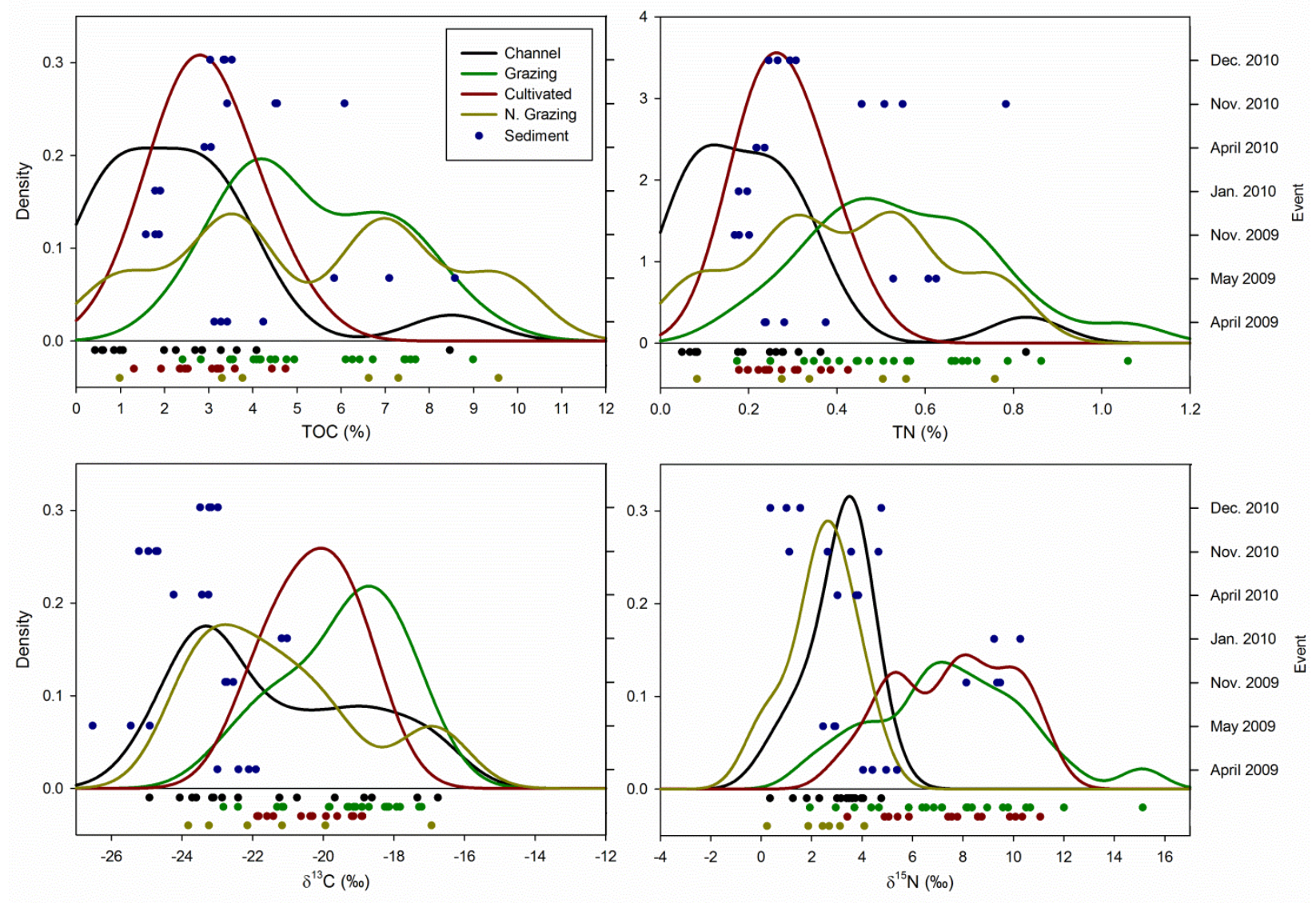

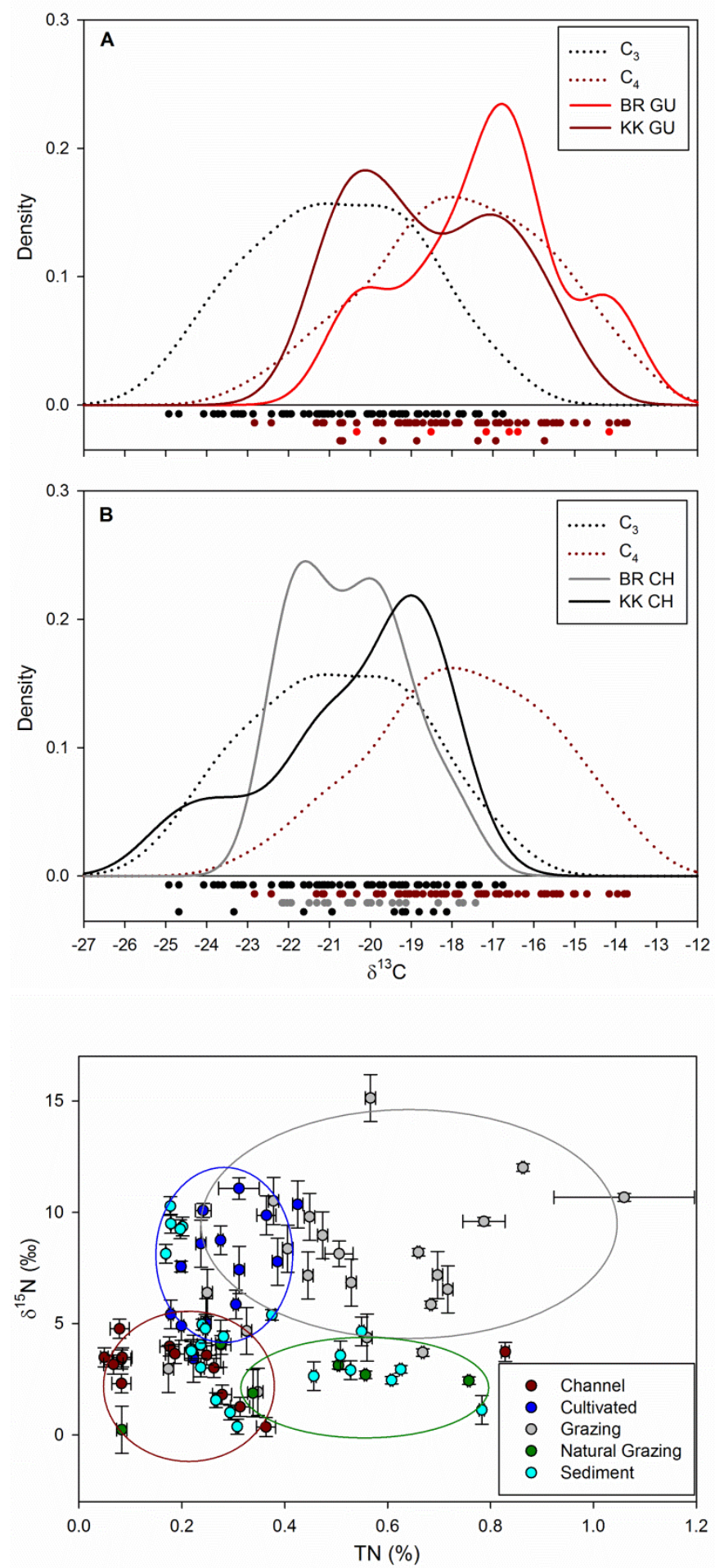